\title{
EURODELTA-Trends, a multi-model experiment of air quality hindcast in Europe over 1990-2010
}

\author{
Augustin Colette ${ }^{1}$, Camilla Andersson ${ }^{2}$, Astrid Manders ${ }^{3}$, Kathleen Mar $^{4}$, Mihaela Mircea ${ }^{5}$, Maria-Teresa Pay ${ }^{6}$, \\ Valentin Raffort ${ }^{7}$, Svetlana Tsyro ${ }^{8}$, Cornelius Cuvelier ${ }^{9, *}$, Mario Adani ${ }^{5}$, Bertrand Bessagnet ${ }^{1}$, Robert Bergström ${ }^{2}$, \\ Gino Briganti $^{5}$, Tim Butler ${ }^{4}$, Andrea Cappelletti ${ }^{5}$, Florian Couvidat ${ }^{1}$, Massimo D'Isidoro ${ }^{5}$, Thierno Doumbia ${ }^{10}$, \\ Hilde Fagerli $^{8}$, Claire Granier ${ }^{10,11,12}$, Chris Heyes ${ }^{13}$, Zig Klimont ${ }^{13}$, Narendra Ojha ${ }^{14}$, Noelia Otero ${ }^{4}$, \\ Martijn Schaap $^{3}$, Katarina Sindelarova ${ }^{10}$, Annemiek I. Stegehuis ${ }^{15}$, Yelva Roustan ${ }^{7}$, Robert Vautard ${ }^{15}$, Erik van \\ Meijgaard $^{16}$, Marta Garcia Vivanco ${ }^{17}$, and Peter Wind ${ }^{8,18}$ \\ ${ }^{1}$ INERIS, Institut National de l'Environnement Industriel et des Risques, Verneuil en Halatte, France \\ ${ }^{2}$ SMHI, Swedish Meteorological and Hydrological Institute Norrköping, Norrköping, Sweden \\ ${ }^{3} \mathrm{TNO}$, Netherlands Institute for Applied Scientific Research, Utrecht, the Netherlands \\ ${ }^{4}$ IASS, Institute for Advanced Sustainability Studies, Potsdam, Germany \\ ${ }^{5}$ ENEA - National Agency for New Technologies, Energy and Sustainable Economic Development, Bologna, Italy \\ ${ }^{6}$ Earth Sciences Department, Barcelona Supercomputing Center-Centro Nacional de Supercomputación, Barcelona, Spain \\ ${ }^{7}$ CEREA, Joint Laboratory Ecole des Ponts ParisTech - EDF R\&D, Champs-Sur-Marne, France \\ ${ }^{8}$ MET Norway, Norwegian Meteorological Institute, Oslo, Norway \\ ${ }^{9}$ European Commission, Joint Research Centre, Ispra, Italy \\ ${ }^{10}$ LATMOS/IPSL, UPMC University Paris 06 Sorbonne Universities, Paris, France \\ ${ }^{11}$ Laboratoire d'Aérologie, Toulouse, France \\ ${ }^{12}$ NOAA Earth System Research Laboratory and Cooperative Institute for Research in Environmental Sciences, \\ University of Colorado, Boulder, CO, USA \\ ${ }^{13}$ IIASA International Institute for Applied Systems Analysis, Laxenburg, Austria \\ ${ }^{14}$ Max-Planck-Institut für Chemie, Mainz, Germany \\ ${ }^{15}$ LSCE/IPSL, Laboratoire CEA/CNRS/UVSQ, Gif-sur-Yvette, France \\ ${ }^{16}$ KNMI, Royal Netherlands Meteorological Institute, De Bilt, the Netherlands \\ ${ }^{17}$ CIEMAT, Madrid, Spain \\ ${ }^{18}$ Faculty of Science and Technology, University of Troms $\varnothing$, Troms $\emptyset$, Norway \\ *retired \\ Correspondence to: Augustin Colette (augustin.colette@ineris.fr)
}

Received: 16 December 2016 - Discussion started: 13 January 2017

Revised: 14 June 2017 - Accepted: 19 June 2017 - Published: 5 September 2017

\begin{abstract}
The EURODELTA-Trends multi-model chemistry-transport experiment has been designed to facilitate a better understanding of the evolution of air pollution and its drivers for the period 1990-2010 in Europe. The main objective of the experiment is to assess the efficiency of air pollutant emissions mitigation measures in improving regional-scale air quality.

The present paper formulates the main scientific questions and policy issues being addressed by the EURODELTA-
\end{abstract}

Trends modelling experiment with an emphasis on how the design and technical features of the modelling experiment answer these questions.

The experiment is designed in three tiers, with increasing degrees of computational demand in order to facilitate the participation of as many modelling teams as possible. The basic experiment consists of simulations for the years 1990, 2000, and 2010. Sensitivity analysis for the same three years using various combinations of (i) anthropogenic emis- 
sions, (ii) chemical boundary conditions, and (iii) meteorology complements it. The most demanding tier consists of two complete time series from 1990 to 2010, simulated using either time-varying emissions for corresponding years or constant emissions.

Eight chemistry-transport models have contributed with calculation results to at least one experiment tier, and five models have - to date - completed the full set of simulations (and 21-year trend calculations have been performed by four models). The modelling results are publicly available for further use by the scientific community.

The main expected outcomes are (i) an evaluation of the models' performances for the three reference years, (ii) an evaluation of the skill of the models in capturing observed air pollution trends for the 1990-2010 time period, (iii) attribution analyses of the respective role of driving factors (e.g. emissions, boundary conditions, meteorology), (iv) a dataset based on a multi-model approach, to provide more robust model results for use in impact studies related to human health, ecosystem, and radiative forcing.

\section{Introduction}

Air pollution is a crucial environmental concern because of its detrimental impacts on health, ecosystems, the built environment, and short-term climate forcing. Whereas it was originally regarded as an urban issue, in the late 1970s the large-scale acidification of precipitation made it clear that at least part of the problem could only be solved through international cooperation (OECD, 1977). This was the background for the establishment of the Convention on Long Range Transboundary Air Pollution (CLRTAP) in 1979. The main vehicles of the LRTAP Convention are the protocols that aim to reduce the emission of various compounds (sulfur in 1985, nitrogen oxides in 1988, volatile organic compounds in 1991, heavy metals and persistent organic pollutants in 1998, and the multi-pollutant multi-effect Gothenburg Protocol to abate acidification, eutrophication, and ground-level ozone in 1999, with subsequent revision in 2012). The design of such mitigation strategies was largely supported by the development of models (chemistry-transport and integrated assessment tools) and monitoring networks.

After several decades of international cooperation, it is timely to take stock of the evidence available to assess the efficiency of the LRTAP Convention and the corresponding emission-ceiling protocols. The executive body of the Convention has therefore requested an assessment of the evolution of air pollution and subsequent effects from its two scientific and technical bodies: (i) the European Monitoring and Evaluation Programme (EMEP) and (ii) the Working Group on Effects (WGE). As a result, the Task Force on Measurement and Modelling (TFMM) of EMEP published an assessment of air pollution trends (Colette et al., 2016), whereas the WGE published an assessment of corresponding effects on health and ecosystems (De Wit et al., 2015), and an overall assessment report encompassing all the activities undertaken under the Convention was also released (Maas and Grennfelt, 2016).

The effects of emissions on the concentrations is rather complex due to (i) the non-linearity of atmospheric chemistry, (ii) the presence of inflow of air pollution due to the intercontinental transport of air pollutants, and (iii) the meteorological variability. This is where chemistry-transport models (CTMs) come into play with the multi-model air quality trend experiment introduced in the present paper.

The LRTAP convention relies in part on the results of the EMEP/MSC-W chemistry-transport model (Simpson et al., 2012a). Since the beginning of the 2000s, the Joint Research Centre of the European Commission initiated a number of multi-model assessments to provide a benchmark for the EMEP/MSC-W model through its comparison with the modelling tools being used by the states and parties to the Convention as part of the Eurodelta project (Bessagnet et al., 2016; van Loon et al., 2007; Thunis et al., 2008). The EURODELTA-Trends (EDT) exercise builds upon this tradition, focusing on the specific context of air quality trend modelling. Its main goal is to assess to what extent observed air pollution trends could be related to emission mitigation, although this overarching question can only be addressed after having assessed the confidence we can have in the models, and in particular in their capacity to reproduce the trends.

In the recent past, several multi-model projects covering a time period of 1 year or less were undertaken, such as the earlier phases of Eurodelta cited above but also the various phases of the AQMEII project (Galmarini et al., 2012, 2017; Rao et al., 2011; Im et al., 2015). However, only a few attempts have been made to address the issue of the long-term evolution of European-scale air quality by means of modelling studies. The first attempts were using only one model as in Vautard et al. (2006), Jonson et al. (2006), and Wilson et al. (2012). A first ensemble was proposed through the European Project CityZen which relied on six models (Colette et al., 2011). While these studies were limited to about 10-year time periods, a 20-year hindcast study was presented in Banzhaf et al. (2015), relying again, however, on a single model. It is therefore timely to engage in a multi-model hindcast of air quality over 2 decades.

The purpose of the present paper is to define the science and policy questions that are addressed by the EDT exercise, and introduce the experimental setup designed to answer these questions. The models participating in the experiment will also be presented, as well as the project database of model results. 


\section{Experimental design}

The main policy focus being addressed in EDT analysis is the assessment of the role of European air pollutant emission reductions in improving air quality over the past 2 decades. Subsequent questions include assessing (1) the role of changes in global air pollution as well as (2) the role of inter-annual meteorological variability. Before addressing such issues, it will be essential to quantify the CTMs' capability in (1) reproducing observed air pollutant concentrations (processes determining air quality: chemistry, physics, transport processes, emissions, meteorology) and (2) capturing the long-term evolution of air quality.

The time period covered by the experiment is 1990-2010. The year 1990 has been chosen as the beginning of the period because that year serves as reference for the Gothenburg Protocol. The end of the period is 2010 because of the availability of underlying forcing data (emissions, boundary conditions (BCs), and meteorology) required for model calculations at the time the work was initiated.

The EDT model experiment is divided into three tiers, targeting various science and policy questions. The tiers also differ in terms of computational demand that allowed the involvement of as many modelling groups as possible. The tiers of experiments are summarised in Table 2. They differ in terms of the number of modelled years to be addressed in the 1990-2010 period and in terms of forcing data used in model calculations for the anthropogenic emissions, the chemical boundary conditions, and the meteorological year. Most of the experiments consist of variations in one or two of these three factors in order to disentangle the role of each forcing. The role of chemical boundary conditions constitutes one notable exception, since two sources of forcing are used: either a global CTM simulation or an observation-based climatology (further details are provided on boundary conditions in Sect. 7).

The first simulation of the EDT experiment is a reference for the year 2010 using the meteorology (M), the chemical boundary conditions (B) and the emissions (E) for that year, named as M10B10E10, with two digits corresponding to the last two digits of the year. They are complemented with simulations for the years 1990 and 2000 (using corresponding meteorology, boundary conditions, and emissions: M90B90E90 and M00B00E00, respectively) to form tier 1A. Tier 1A will allow testing of the accuracy of all CTMs in simulating pollution changes for the near past (1990, 2000, and 2010), at a lower computational cost than running the full 21-year period.

Tier 1B is dedicated to the first two sensitivity experiments, for which the meteorology and the boundary conditions are those of the year 2010, but the emissions correspond to 1990 and 2000 (M10B10E90 and M10B10E00). They will allow assessment of the individual impact of emission changes alone (E10 vs. E90 and E10 vs. E00) by comparison with tier 1A (specifically M10B10E10).
In tier $2 \mathrm{~A}$, two more sensitivity simulations are performed for the meteorological year 2010, using emissions and boundary conditions of 1990 and 2000 (M10B90E90 and $\mathrm{M} 10 \mathrm{~B} 00 \mathrm{E} 00$, respectively). By comparison with tier 1B, they will allow the assessment of the impact of global chemical background changes on European air quality between the years 1990 and 2010, and also for the sub-periods 1990-2000 and 2000-2010 (B10 vs. B90 and B10 vs. B00).

Tier $2 \mathrm{~B}$ is an alternate set of reference simulations for 1990,2000 , and 2010, in which boundary conditions provided by a global model (C) instead of the observationbased boundaries are used (M90C90E90, M00C00E00, $\mathrm{M} 10 \mathrm{C} 10 \mathrm{E} 10)$. It will allow assessment of the uncertainty related to the large-scale chemical forcing by comparison with tier $1 \mathrm{~A}$.

Tier $2 \mathrm{C}$ is a complement to tier $2 \mathrm{~A}$ using the meteorology of 2000 and two combinations of 1990 and 2000 boundary conditions and emissions (M00B90E90, M00B00E90). These additional simulations are required to perform the attribution analysis for the concentration changes between 1990 and 2000, whereas the simulations required for the attribution of driving factors between 1990 and 2010 and between 2000 and 2010 are dealt with in tiers $1 \mathrm{~A}, 1 \mathrm{~B}$, and $2 \mathrm{~A}$.

Tier 3A consists of 21-year simulations covering 19902010, using meteorology, boundary conditions and emissions for the respective years (MyyByyEyy, with yy being the 2digit year between 1990 and 2010). It will be used to assess the capability of the models to capture observed trends in air quality by means of comparisons with available measurements. Fewer modelling teams delivered results for this higher tier of experiments, and therefore model uncertainty will be put in perspective with the spread of the whole ensemble in modelling tier 1A (1990, 2000, and 2010).

Tier 3B is the last sensitivity experiment in which 21year simulations are performed using the 2010 emissions for the complete period (MyyByyE10, with yy varying from 90 to 10 , refering to the years 1990 to 2010). By comparison with tier $3 \mathrm{~A}$, it will allow the determination of the role of inter-annual meteorology and chemical boundary condition changes vs. the role of European emission changes.

Thus, the complete series of model runs included for each air quality model is 5 annual simulations for tier 1,7 more simulations for tier 2 , and $39(2 \times 21$ minus 1 overlap for 2010, and 2 annual simulations belonging to tier 1A: M90B90E90 and M00B00E00) more simulated years for tier 3.

Figure 1 provides the schematics of the various combinations of simulations required to perform the attribution analysis for any period of time between the three reference years (1990, 2000, and 2010). The simulations labelled in black are covered by the above simulation plan. They are needed for the assessment of the relative role of emissions, meteorology, and boundary condition changes.

The main limitations of the simulation plan are that (i) the three selected meteorological years may be not representa- 
Table 1. Main features of the chemistry-transport models involved in the EURODELTA-Trends modelling exercise.

\begin{tabular}{|c|c|c|c|c|c|c|c|c|}
\hline Model & CHIMERE & CMAQB & EMEP & $\begin{array}{l}\text { LOTOS- } \\
\text { EUROS }\end{array}$ & MATCH & MINNI & POLYPHEMUS & WRF-CHEM \\
\hline Version & $\begin{array}{l}\text { Modified } \\
\text { CHIMERE2013 }\end{array}$ & V5.0.2 & rv4.7 & $\mathrm{v} 1.10 .005$ & $\begin{array}{l}\text { VSOA April } \\
2016\end{array}$ & $\mathrm{~V} 4.7$ & V1.9.1 & $\mathrm{V} 3.5 .1$ \\
\hline Operator & INERIS & BSC & MET Norway & TNO & SMHI & $\begin{array}{l}\text { ENEA/Arianet } \\
\text { S.r.l. }\end{array}$ & CEREA & IASS \\
\hline $\begin{array}{l}\text { Chemistry/ } \\
\text { Meteorology } \\
\text { coupling }\end{array}$ & Offline & Offline & Offline & Offline & Offline & Offline & Offline & Online \\
\hline $\begin{array}{l}\text { Name and res- } \\
\text { olution of the } \\
\text { meteorological } \\
\text { driver }\end{array}$ & $\begin{array}{l}\text { WRF (common } \\
\text { driver after } \\
\text { Stegehuis et al., } \\
2015 \text { ). } 0.44^{\circ}\end{array}$ & WRF. $25 \mathrm{~km}$ & $\begin{array}{l}\text { WRF (common } \\
\text { driver after } \\
\text { (Stegehuis } \\
\text { et al., 2015). } \\
0.44^{\circ}\end{array}$ & $\begin{array}{l}\text { RACOMO2, } \\
0.22^{\circ}\end{array}$ & $\begin{array}{l}\text { HIRLAM } \\
\text { EURO4M } \\
\text { reanalysis, } \\
\text { approx. } 22 \mathrm{~km}\end{array}$ & $\begin{array}{l}\text { WRF (common } \\
\text { driver after } \\
\text { Stegehuis et al., } \\
2015 \text { ). } 0.44^{\circ}\end{array}$ & $\begin{array}{l}\text { WRF (common } \\
\text { driver after } \\
\text { Stegehuis et al., } \\
2015 \text { ). } 0.44^{\circ}\end{array}$ & $\begin{array}{l}\text { WRF, approx. } 25 \mathrm{~km} \\
\text { (common driver used } \\
\text { for initial and lateral } \\
\text { boundary conditions, } \\
\text { and for applying } \\
\text { four-dimensional data } \\
\text { assimilation (FDDA), } \\
\text { with coefficients as } \\
\text { described in Mar et } \\
\text { al. (2016).) }\end{array}$ \\
\hline Vertical layers & 9 sigma & 15 sigma & 20 sigma & $\begin{array}{l}5 \text { (4 dynamic } \\
\text { layers and a } \\
\text { surface layer })\end{array}$ & $\begin{array}{l}39 \text { hybrid levels } \\
\text { of the meteo- } \\
\text { rological model } \\
\text { layers }\end{array}$ & $\begin{array}{l}16 \text { fixed terrain- } \\
\text { following } \\
\text { layers }\end{array}$ & $\begin{array}{l}9 \text { Fixed terrain- } \\
\text { following } \\
\text { layers }\end{array}$ & 35 terrain-following \\
\hline Vertical extent & $500 \mathrm{hPa}$ & $50 \mathrm{hPa}$ & $100 \mathrm{hPa}$ & $5000 \mathrm{~m}$ & $\begin{array}{l}\text { ca. } 5000 \mathrm{~m} \\
(4700-6000 \mathrm{~m})\end{array}$ & $10000 \mathrm{~m}$ & $12000 \mathrm{~m}$ & $10 \mathrm{hPa}$ \\
\hline $\begin{array}{l}\text { Depth first } \\
\text { layer }\end{array}$ & $20 \mathrm{~m}$ & $40 \mathrm{~m}$ & $90 \mathrm{~m}$ & $25 \mathrm{~m}$ & ca. $60 \mathrm{~m}$ & $40 \mathrm{~m}$ & $40 \mathrm{~m}$ & $50 \mathrm{~m}$ \\
\hline $\begin{array}{l}\text { Surface } \\
\text { concentration }\end{array}$ & $\begin{array}{l}\text { First model } \\
\text { level }\end{array}$ & $\begin{array}{l}\text { First model } \\
\text { level }\end{array}$ & $\begin{array}{l}\text { Downscaled to } \\
3 \mathrm{~m} \text { using dry } \\
\text { deposition ve- } \\
\text { locity and simi- } \\
\text { larity theory }\end{array}$ & $\begin{array}{l}\text { Downscaled to } \\
3 \mathrm{~m}\end{array}$ & $\begin{array}{l}\text { Downscaled to } \\
3 \mathrm{~m}\end{array}$ & $\begin{array}{l}\text { First model } \\
\text { level }\end{array}$ & $\begin{array}{l}\text { First model } \\
\text { level }\end{array}$ & First model level \\
\hline Biogenic VOC & $\begin{array}{l}\text { MEGAN } \\
\text { model v2.1 } \\
\text { with high- } \\
\text { resolution } \\
\text { spatial and } \\
\text { temporal leaf } \\
\text { area index } \\
\text { (LAI; Yuan et } \\
\text { al., 2011) and } \\
\text { recomputed } \\
\text { emissions fac- } \\
\text { tors based on } \\
\text { the land use } \\
\text { (Guenther et } \\
\text { al., 2006) }\end{array}$ & $\begin{array}{l}\text { MEGAN } \\
\text { model v2.04 } \\
\text { (Guenther et } \\
\text { al., 2006) }\end{array}$ & $\begin{array}{lr}\text { Based upon } \\
\text { maps of } 115 \\
\text { species from } \\
\text { Koeble and } \\
\text { Seufert }(2001) \text {, } \\
\text { and hourly } \\
\text { temperature } \\
\text { and light us- } \\
\text { ing Guenther } \\
\text { et al. (1993, } \\
\text { 1994). See } \\
\text { Simpson et } \\
\text { al. (1995, } \\
\text { 2012a) }\end{array}$ & $\begin{array}{lr}\text { Based } & \text { upon } \\
\text { maps of } & 115 \\
\text { species } & \text { from } \\
\text { Koeble } & \text { and } \\
\text { Seufert } & (2001), \\
\text { and hourly tem- } \\
\text { perature and } \\
\text { light (Guenther } \\
\text { et al., 1991, } \\
\begin{array}{lr}\text { 1993). } \\
\text { Beltman ee } \\
\text { al. (2013) }\end{array}\end{array}$ & $\begin{array}{lr}\text { Simpson } & \text { et } \\
\text { al. } & \text { (2012a), } \\
\text { based } & \text { on } \\
\text { hourly } & \text { tem- } \\
\text { perature } & \text { and } \\
\text { light } & \end{array}$ & $\begin{array}{l}\text { MEGAN v2.04 } \\
\text { (Guenther et } \\
\text { al., 2006) }\end{array}$ & $\begin{array}{l}\text { MEGAN } \\
\text { V2.04 (Guen- } \\
\text { ther et al., } \\
2006)\end{array}$ & $\begin{array}{l}\text { MEGAN v2.04 (Guen- } \\
\text { ther et al., 2006) }\end{array}$ \\
\hline Forest fires & None & None & None & None & None & None & None & None \\
\hline Soil-NO & $\begin{array}{l}\text { MEGAN } \\
\text { model v2.04 }\end{array}$ & $\begin{array}{l}\text { MEGAN } \\
\text { model v2.04 }\end{array}$ & $\begin{array}{l}\text { See in Simpson } \\
\text { et al. (2012a) }\end{array}$ & Not used here & None & MEGAN v2.04 & $\begin{array}{l}\text { MEGAN } \\
\text { V2.04 }\end{array}$ & MEGAN v2.04 \\
\hline Lightning & None & None & $\begin{array}{l}\text { Monthly cli- } \\
\text { matological } \\
\text { fields, Köhler } \\
\text { et al. (1995) }\end{array}$ & None & None & None & None & None \\
\hline Sea salt & Monahan (1986) & $\begin{array}{l}\text { Open ocean } \\
\text { and surface } \\
\text { zone (Kelly et } \\
\text { al., 2010) }\end{array}$ & $\begin{array}{l}\text { Monahan (1986) } \\
\text { and Martensson } \\
\text { et al. (2003), } \\
\text { see Tsyro et } \\
\text { al. (2011) }\end{array}$ & $\begin{array}{l}\text { Martensson } \\
\text { et al. (2003) } \\
\text { and Mona- } \\
\text { han (1986). } \\
\text { See Schaap et } \\
\text { al. (2009) }\end{array}$ & $\begin{array}{l}\text { Based on pa- } \\
\text { rameterisation } \\
\text { by Sofiev et } \\
\text { al. (2011) }\end{array}$ & $\begin{array}{l}\text { Zhang } \\
\text { al. (2005) }\end{array}$ & Monahan (1986) & $\begin{array}{l}\text { Gong et al. (1997), } \\
\text { O'Dowd et al. (1997) }\end{array}$ \\
\hline $\begin{array}{l}\text { Windblown } \\
\text { dust }\end{array}$ & $\begin{array}{l}\text { Vautard et } \\
\text { al. (2005), not } \\
\text { used here }\end{array}$ & None & $\begin{array}{l}\text { See Simpson et } \\
\text { al. (2012a) }\end{array}$ & $\begin{array}{l}\text { Schaap et } \\
\text { al. (2009) }\end{array}$ & Not used here & $\begin{array}{l}\text { Vautard et } \\
\text { al. }(2005)\end{array}$ & None & None \\
\hline $\begin{array}{l}\text { Dust traffic } \\
\text { suspension }\end{array}$ & None & None & $\begin{array}{l}\text { Denier van } \\
\begin{array}{ll}\text { der Gon et } \\
\text { al. }(2010)\end{array}\end{array}$ & None & Not used here & None & None & None \\
\hline
\end{tabular}


Table 1. Continued.

\begin{tabular}{|c|c|c|c|c|c|c|c|c|}
\hline Model & CHIMERE & CMAQB & EMEP & $\begin{array}{l}\text { LOTOS- } \\
\text { EUROS }\end{array}$ & MATCH & MINNI & POLYPHEMUS & WRF-CHEM \\
\hline $\begin{array}{l}\text { Land-use } \\
\text { database }\end{array}$ & $\begin{array}{l}\text { GLOBCOVER } \\
\text { ( } 24 \text { classes) }\end{array}$ & $\begin{array}{l}\text { Corine Land } \\
\text { Cover } 2006(44 \\
\text { classes) }\end{array}$ & $\begin{array}{l}\text { CCE/SEI } \\
\text { for Europe, } \\
\text { elsewhere } \\
\text { GLC2000 }\end{array}$ & $\begin{array}{l}\text { Corine Land } \\
\text { Cover } 2000(13 \\
\text { classes })\end{array}$ & CCE/SEI for Europe & $\begin{array}{l}\text { Corine Land } \\
\text { Cover } 2006(22 \\
\text { classes })\end{array}$ & $\begin{array}{l}\text { Global Land } \\
\text { Cover } 2000(24 \\
\text { classes })\end{array}$ & $\begin{array}{l}\text { 24-category } \\
\text { USGS land use }\end{array}$ \\
\hline $\begin{array}{l}\text { Advection } \\
\text { scheme }\end{array}$ & van Leer (1984) & $\begin{array}{l}\text { Horizontal: } \\
\text { WRF-based } \\
\text { scheme, verti- } \\
\text { cal: piecewise } \\
\text { parabolic } \\
\text { method }\end{array}$ & Bott (1989) & Walcek (2000) & $\begin{array}{l}\text { Fourth-order mass- } \\
\text { conserved advection } \\
\text { scheme based on } \\
\text { Bott (1989) }\end{array}$ & $\begin{array}{l}\text { Blackman cu- } \\
\text { bic polynomi- } \\
\text { als (Yamartino, } \\
\text { 1993) }\end{array}$ & $\begin{array}{l}\text { Third-order } \\
\text { Direct Space } \\
\text { Time scheme } \\
\text { (Spee, 1998) } \\
\text { with Koren- } \\
\text { Sweby flux } \\
\text { limiter function }\end{array}$ & $\begin{array}{l}\text { Runge-Kutta } \\
\text { third order }\end{array}$ \\
\hline $\begin{array}{l}\text { Vertical } \\
\text { diffusion }\end{array}$ & $\begin{array}{l}\text { vertical diffu- } \\
\text { sion coefficient } \\
(\mathrm{Kz}) \text { approach } \\
\text { following } \\
\text { Troen and } \\
\text { Mahrt (1986) }\end{array}$ & $\begin{array}{l}\text { ACM2 PBL } \\
\text { scheme (Pleim, } \\
\text { 2007) }\end{array}$ & $\begin{array}{l}\mathrm{Kz} \text { approach } \\
\text { following } \\
\text { O'Brien (1970) } \\
\text { and Jeričevič et } \\
\text { al. (2010) }\end{array}$ & $\begin{array}{l}\text { Kz approach } \\
\text { Yamartino et } \\
\text { al. (2004) }\end{array}$ & $\begin{array}{l}\text { Implicit mass conser- } \\
\text { vative Kz approach } \\
\text { (see Robertson et } \\
\text { al., 1999); } \\
\text { Boundary layer pa- } \\
\text { rameterisation as } \\
\text { detailed in Robertson et } \\
\text { al. (1999) forms the ba- } \\
\text { sis for vertical diffusion } \\
\text { and dry deposition }\end{array}$ & $\begin{array}{l}\mathrm{Kz} \text { approach } \\
\text { following } \\
\text { Lange (1989) }\end{array}$ & $\begin{array}{l}\mathrm{Kz} \text { approach } \\
\text { following } \\
\text { Troen and } \\
\text { Mahrt (1986) }\end{array}$ & $\begin{array}{l}\text { Yonsei Uni- } \\
\text { versity PBL } \\
\text { scheme (Hong } \\
\text { et al., 2004) }\end{array}$ \\
\hline Dry deposition & $\begin{array}{l}\text { Resistance } \\
\text { approach (Em- } \\
\text { berson et al., } \\
2000 a, b)\end{array}$ & $\begin{array}{l}\text { Resistance ap- } \\
\text { proach (Venka- } \\
\text { tram and Pleim, } \\
\text { 1999) }\end{array}$ & $\begin{array}{l}\text { Resistance } \\
\text { approach for } \\
\text { gases (Venka- } \\
\text { tram and } \\
\text { Pleim, 1999); } \\
\text { for aerosols, } \\
\text { Simpson et } \\
\text { al. (2012a) }\end{array}$ & $\begin{array}{l}\text { Resistance } \\
\text { approach, DE- } \\
\text { PAC3.11 for } \\
\text { gases, Van Zan- } \\
\text { ten et al. (2010) } \\
\text { and Zhang et } \\
\text { al. (2001) for } \\
\text { aerosols }\end{array}$ & $\begin{array}{l}\text { Resistance approach } \\
\text { depending on aerody- } \\
\text { namic resistance and } \\
\text { land use (vegetation). } \\
\text { Similar to Andersson et } \\
\text { al. (2007) }\end{array}$ & $\begin{array}{l}\text { Resistance } \\
\text { model based on } \\
\text { Wesely (1989) }\end{array}$ & $\begin{array}{l}\text { Resistance } \\
\text { approach for } \\
\text { gases (Zhang } \\
\text { et al., 2003) } \\
\text { and aerosols } \\
\text { (Zhang et al., } \\
\text { 2001) }\end{array}$ & $\begin{array}{l}\text { Wesely (1989) } \\
\text { and Erisman et } \\
\text { al. (1994) }\end{array}$ \\
\hline $\begin{array}{l}\text { Ammonia } \\
\text { compensation } \\
\text { points }\end{array}$ & None & None & $\begin{array}{l}\text { None, but zero } \\
\mathrm{NH}_{3} \text { deposition } \\
\text { over growing } \\
\text { crops }\end{array}$ & $\begin{array}{l}\text { Only for } \mathrm{NH}_{3} \\
\text { (for stomatal, } \\
\text { external leaf } \\
\text { surface and soil } \\
(=0) \text { ) }\end{array}$ & None & None & None & None \\
\hline $\begin{array}{l}\text { Stomatal } \\
\text { resistance }\end{array}$ & $\begin{array}{l}\text { Emberson et } \\
\text { al. }(2000 a, b)\end{array}$ & Wesely (1989) & $\begin{array}{l}\text { DO3SE- } \\
\text { EMEP: } \\
\text { Emberson et } \\
\text { al. (2000a, b), } \\
\text { Tuovinen et } \\
\text { al. (2004), } \\
\text { Simpson et } \\
\text { al. (2012a) }\end{array}$ & $\begin{array}{l}\text { Emberson et } \\
\text { al. }(2000 \mathrm{a}, \mathrm{b})\end{array}$ & $\begin{array}{l}\text { Simple, seasonally } \\
\text { varying, diurnal } \\
\text { variation of surface } \\
\text { resistance for gases } \\
\text { with stomatal re- } \\
\text { sistance (similar to } \\
\text { Andersson et al., 2007) }\end{array}$ & Wesely (1989) & $\begin{array}{l}\text { Zhang et } \\
\text { al. (2003) }\end{array}$ & $\begin{array}{l}\text { Wesely (1989) } \\
\text { and Erisman et } \\
\text { al. (1994) }\end{array}$ \\
\hline $\begin{array}{l}\text { Wet deposition } \\
\text { gases }\end{array}$ & $\begin{array}{l}\text { In-cloud and } \\
\text { sub-cloud } \\
\text { scavenging } \\
\text { coefficients }\end{array}$ & $\begin{array}{l}\text { In-cloud and } \\
\text { sub-cloud scav- } \\
\text { enging which } \\
\text { depends on } \\
\text { Henry's } \\
\text { law constants, } \\
\text { dissociation } \\
\text { constants and } \\
\text { cloud water pH } \\
\text { (Chang et al., } \\
\text { 1987) }\end{array}$ & $\begin{array}{l}\text { In-cloud and } \\
\text { sub-cloud } \\
\text { scavenging } \\
\text { coefficients }\end{array}$ & $\begin{array}{l}\text { sub-cloud } \\
\text { scavenging } \\
\text { coefficient }\end{array}$ & $\begin{array}{l}\text { In-cloud scavenging of } \\
\text { some species based on } \\
\text { Henry's law constants. } \\
\text { Simple in-cloud and } \\
\text { sub-cloud scavenging } \\
\text { coefficients for other } \\
\text { gases. }\end{array}$ & $\begin{array}{l}\text { In-cloud and } \\
\text { sub-cloud } \\
\text { scavenging } \\
\text { coefficients } \\
\text { (EMEP, 2003) }\end{array}$ & 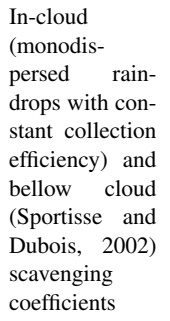 & $\begin{array}{l}\text { In-cloud and } \\
\text { sub-cloud } \\
\text { scavenging } \\
\text { coefficients }\end{array}$ \\
\hline $\begin{array}{l}\text { Wet deposition } \\
\text { particles }\end{array}$ & $\begin{array}{l}\text { In-cloud and } \\
\text { sub-cloud } \\
\text { scavenging }\end{array}$ & $\begin{array}{l}\text { In-cloud and } \\
\text { sub-cloud } \\
\text { scavenging }\end{array}$ & $\begin{array}{l}\text { In-cloud and } \\
\text { sub-cloud } \\
\text { scavenging }\end{array}$ & $\begin{array}{l}\text { sub-cloud } \\
\text { scavenging } \\
\text { coefficient }\end{array}$ & $\begin{array}{l}\text { In-cloud and sub-cloud } \\
\text { scavenging. Similar to } \\
\text { Simpson et al. (2012a) }\end{array}$ & $\begin{array}{l}\text { In-cloud and } \\
\text { sub-cloud } \\
\text { scavenging } \\
\text { coefficients }\end{array}$ & $\begin{array}{l}\text { In-cloud (as } \\
\text { for gas) and } \\
\text { bellow cloud } \\
\text { (Slinn, 1983) } \\
\text { scavenging } \\
\text { coefficients }\end{array}$ & $\begin{array}{l}\text { In-cloud and } \\
\text { sub-cloud } \\
\text { scavenging } \\
\text { coefficients }\end{array}$ \\
\hline $\begin{array}{l}\text { Gas-phase } \\
\text { chemistry }\end{array}$ & MELCHIOR2 & $\begin{array}{l}\text { CB-05 with } \\
\text { chlorine chem- } \\
\text { istry extensions } \\
\text { (Yarwood et al., } \\
\text { 2005) }\end{array}$ & $\begin{array}{l}\text { EmChem09 } \\
\text { (Simpson et al., } \\
\text { 2012a) }\end{array}$ & TNO-CBM-IV & $\begin{array}{l}\text { Based on EMEP } \\
\text { (Simpson et al., 2012), } \\
\text { with modified isoprene } \\
\text { chemistry } \\
\text { (Carter, 1996; Langner } \\
\text { et al., 1998) }\end{array}$ & $\begin{array}{l}\text { SAPRC99 } \\
(\text { Carter, 2000) }\end{array}$ & $\begin{array}{l}\text { CB-05 } \\
\text { (Yarwood } \\
\text { et al., 2005) }\end{array}$ & $\begin{array}{l}\text { RADM2 } \\
\text { (Stockwell et } \\
\text { al., 1990) with } \\
\text { updates made } \\
\text { to inorganic } \\
\text { rate coefficients } \\
\text { as described } \\
\text { in Supplement } \\
\text { to Mar et } \\
\text { al. (2016). }\end{array}$ \\
\hline
\end{tabular}


Table 1. Continued.

\begin{tabular}{|c|c|c|c|c|c|c|c|c|}
\hline Model & CHIMERE & CMAQB & EMEP & $\begin{array}{l}\text { LOTOS- } \\
\text { EUROS }\end{array}$ & MATCH & MINNI & POLYPHEMUS & WRF-CHEM \\
\hline $\begin{array}{l}\text { Cloud } \\
\text { chemistry }\end{array}$ & $\begin{array}{l}\text { Aqueous } \mathrm{SO}_{2} \text { chem- } \\
\text { istry and } \mathrm{pH} \text {-dependent } \\
\mathrm{SO}_{2} \text { chemistry }\end{array}$ & $\begin{array}{l}\text { Aqueous } \mathrm{SO}_{2} \\
\text { chemistry } \\
\text { (Walcek and } \\
\text { Taylor, 1986) }\end{array}$ & $\begin{array}{l}\text { Aqueous } \mathrm{SO}_{2} \\
\text { chemistry, } \\
\text { pH-dependent }\end{array}$ & $\begin{array}{l}\text { Aqueous } \mathrm{SO}_{2} \\
\text { chemistry, } \\
\text { pH-dependent } \\
\text { (Banzhaf et al., } \\
\text { 2012) }\end{array}$ & $\begin{array}{l}\text { Aqueous } \quad \mathrm{SO}_{2} \\
\text { chemistry }\end{array}$ & $\begin{array}{l}\text { Aqueous } \mathrm{SO}_{2} \\
\text { chemistry } \\
\text { (Seinfeld and } \\
\text { Pandis, 1998) }\end{array}$ & $\begin{array}{l}\text { Aqueous } \mathrm{SO}_{2} \\
\text { chemistry } \\
\text { (Seinfeld and } \\
\text { Pandis, 1998) }\end{array}$ & None \\
\hline Coarse nitrate & $\begin{array}{l}\text { No reaction with } \mathrm{Ca} \\
\text { even if reaction with } \\
\mathrm{Na} \text { is taken into ac- } \\
\text { count. Coarse nitrate } \\
\text { might exist with trans- } \\
\text { fer from smaller parti- } \\
\text { cles }\end{array}$ & None & $\begin{array}{l}\text { Two formation } \\
\text { rates of coarse } \\
\mathrm{NO}_{3} \text { from } \\
\mathrm{HNO}_{3} \text { for rel- } \\
\text { ative humidity } \\
\text { below/above } \\
90 \%\end{array}$ & $\begin{array}{l}\text { Wichink Kruit } \\
\text { et al. (2012) }\end{array}$ & $\begin{array}{l}\text { Yes, transfer } \\
\text { of } \mathrm{HNO}_{3}(\mathrm{~g}) \text { to } \\
\text { aerosol nitrate } \\
\text { using rate from } \\
\text { Strand and } \\
\text { Hov (1994) }\end{array}$ & None & $\begin{array}{l}\text { No heteroge- } \\
\text { neous nitrate } \\
\text { formation }\end{array}$ & None \\
\hline $\begin{array}{l}\text { Ammonium ni- } \\
\text { trate } \\
\text { equilibrium }\end{array}$ & $\begin{array}{l}\text { ISORROPIA v2.1 } \\
\text { (Nenes et al., 1999) }\end{array}$ & ISORROPIAv2.1 & $\begin{array}{l}\text { MARS } \\
\text { (Binkowski } \\
\text { and Shankar, } \\
\text { 1995) }\end{array}$ & $\begin{array}{l}\text { ISORROPIA } \\
\text { v. } 2\end{array}$ & $\begin{array}{l}\text { RH- \& T- } \\
\text { dependent } \\
\text { equilibrium } \\
\text { constant } \\
\text { (Mozurkewich, } \\
\text { 1993) }\end{array}$ & $\begin{array}{l}\text { ISORROPIA } \\
\text { v1.7 (Nenes et } \\
\text { al., 1998) }\end{array}$ & $\begin{array}{l}\text { ISORROPIA } \\
\text { v1.7 (Nenes et } \\
\text { al., 1999) }\end{array}$ & $\begin{array}{l}\text { MARS } \\
\text { (Binkowski } \\
\text { and Shankar, } \\
\text { 1995) }\end{array}$ \\
\hline SOA formation & $\begin{array}{l}\mathrm{H}_{2} \mathrm{O} \text { (Couvidat et al., } \\
\text { 2012) mechanism cou- } \\
\text { pled with the thermo- } \\
\text { dynamic model SOAP } \\
\text { (Couvidat and Sartelet, } \\
2015 \text { ) }\end{array}$ & $\begin{array}{l}\text { SORGAM } \\
\text { module (Schell } \\
\text { et al., 2001) }\end{array}$ & $\begin{array}{l}\text { VBS-NPAS } \\
\text { (Simpson et al., } \\
\text { 2012a) }\end{array}$ & Not used here & $\begin{array}{l}\text { Similar to } \\
\text { VBS-NPNA } \\
\text { (Bergström et } \\
\text { al., 2012) }\end{array}$ & $\begin{array}{l}\text { SORGAM } \\
\text { module (Schell } \\
\text { et al., 2001) }\end{array}$ & $\begin{array}{l}\mathrm{H}_{2} \mathrm{O} \text { (Couvidat } \\
\text { et al., 2012) }\end{array}$ & $\begin{array}{l}\text { SORGAM } \\
\text { module (Schell } \\
\text { et al., 2001) }\end{array}$ \\
\hline $\begin{array}{l}\text { Volatility basis } \\
\text { set for aerosols }\end{array}$ & None & None & $\begin{array}{l}\text { Simpson et } \\
\text { al. }(2012 a) \text {, } \\
\text { Bergström et } \\
\begin{array}{l}\text { al. }(2012)\end{array}\end{array}$ & Not used here & $\begin{array}{l}\text { Yes, based on } \\
\text { Bergström et } \\
\text { al. }(2012)\end{array}$ & None & None & None \\
\hline Aerosol model & 9 bins $(10 \mathrm{~nm}$ to $10 \mu \mathrm{m})$ & $\begin{array}{l}\text { AERO5 } \\
\text { Carlton et } \\
\text { al. (2010), } \\
\text { log-normal } \\
\text { approach (three } \\
\text { modes) }\end{array}$ & $\begin{array}{l}\text { Bulk- approach } \\
\text { (fine and coarse } \\
\text { modes) }\end{array}$ & $\begin{array}{l}\text { Bulk- approach } \\
\text { (two modes) }\end{array}$ & Bulk approach & $\begin{array}{l}\text { AERO3 } \\
\text { (Binkowski, } \\
\text { 1999); three } \\
\text { modes: Aitken, } \\
\text { accumulation, } \\
\text { coarse }\end{array}$ & $\begin{array}{l}\text { five bins }(0.01- \\
10 \mu \mathrm{m})\end{array}$ & $\begin{array}{l}\text { MADE (Ack- } \\
\text { ermann et al., } \\
1998)\end{array}$ \\
\hline $\begin{array}{l}\text { Aerosol } \\
\text { physics }\end{array}$ & $\begin{array}{l}\text { Coagulation/ condensa- } \\
\text { tion/ nucleation } \\
\text { computation of the wet } \\
\text { diameter for each bins } \\
\text { as a function of humid- } \\
\text { ity (used for coagula- } \\
\text { tion, condensation, de- } \\
\text { position) }\end{array}$ & $\begin{array}{l}\text { Coagulation/ } \\
\text { condensation/ } \\
\text { nucleation }\end{array}$ & Not used here & Not used here & Not used here & $\begin{array}{l}\text { Coagulation/ } \\
\text { condensation/ } \\
\text { nucleation }\end{array}$ & $\begin{array}{l}\text { Coagulation/ } \\
\text { Condensation }\end{array}$ & $\begin{array}{l}\text { Coagulation/ } \\
\text { condensation/ } \\
\text { nucleation }\end{array}$ \\
\hline
\end{tabular}

tive, or atypical, for the full period and (ii) the lack of interaction by considering $2^{2}$ combinations instead of the $2^{3}$ combinations required to cover the whole space of factors (Stein and Alpert, 1993). In the forthcoming attribution study these limitations will be explored by (i) comparing trend (tier 3A) and sensitivity (tier $1 \& 2$ ) tiers and (ii) including additional simulations for the $2^{3}$ possible combinations from one of the models (CHIMERE).

\section{Participating models}

Eight European modelling teams submitted their calculation results to the EDT database for at least one tier of experiment (see the experiment design in Sect. 2) using state-of-the-art air quality models: CHIMERE (Menut et al., 2013; Mailler et al., 2017), CMAQ (Byun and Schere, 2006), EMEP/MSC-W (Simpson et al., 2012), LOTOS-EUROS (Schaap et al., 2008;
Manders et al., 2017), MATCH (Robertson et al., 1999), MINNI (Mircea et al., 2016), Polyphemus (Mallet et al., 2007), and WRF-Chem (Grell et al., 2005; Mar et al., 2016). The main specifications of the eight participating models are summarised in Table 1 (note that they can differ from the public release of the various models according to the elements provided in the table).

The representation of physical and chemical processes differs in the models. The vertical distribution of model layers (including altitude of the top layer and derivation of surface concentrations at $3 \mathrm{~m}$ height in the case of EMEP, LOTOSEUROS, and MATCH) is not prescribed either. However, as further explained in the article, the other features of the model setup are largely constrained by the experiment input data such as forcing meteorology, boundary conditions, emissions, and the experiment characteristics such as horizontal domain and resolution. Only one of the participat- 

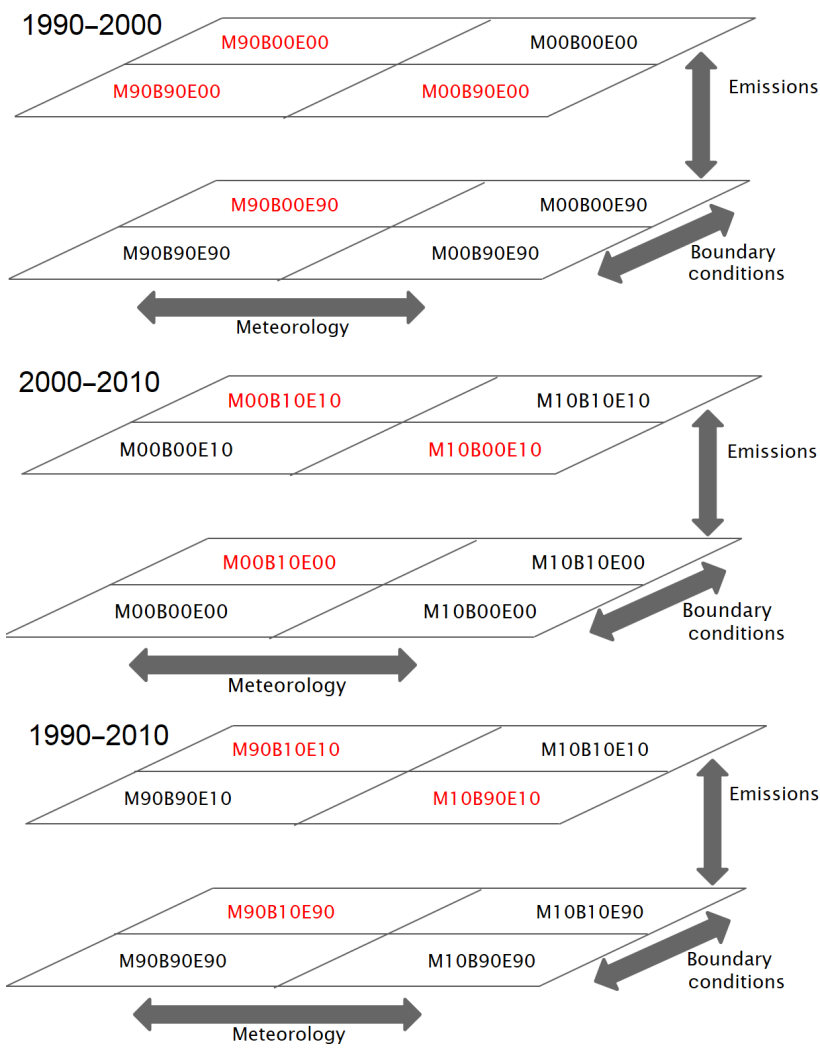

Figure 1. Combination of sensitivity simulations required to perform the analysis of the contribution of (i) meteorology, (ii) boundary conditions, and (iii) emission changes for the 1990-2000, 20002010, and 1990-2010 years from the top to the bottom. The key to EDT model simulations provides the 2-digit modelled year for meteorology (M), boundary conditions (B), and emissions (E). Black labels are for the simulations included in the experiment, and red labels are the combinations not produced in any of the tiers of experiments.

ing models included online coupled chemistry-meteorology (WRF-Chem), while all the other models are offline CTMs.

\section{Modelling domain}

The modelling domain is displayed in Fig. 2. The domain follows a regular latitude-longitude projection (plate carrée projection) with increments of 0.25 and $0.4^{\circ}$ in latitude and longitude, respectively, which is about $25 \mathrm{~km} \times 25 \mathrm{~km}$ at European latitudes. The total coverage extends from $17^{\circ} \mathrm{W}$ to $39.8^{\circ} \mathrm{E}$ and from 32 to $70^{\circ} \mathrm{N}$. All the participating models use the same modelling domain, with only one exception: CMAQB uses a Lambert conformal conic projection map with $25 \mathrm{~km}$ resolution and delivered their results on the common grid. The southeasternmost part of the domain is not included in the CMAQB modelling domain.

\section{Meteorology}

The horizontal resolution of available global meteorological reanalyses over the $1990-2010$ period is considered too coarse to drive regional-scale CTMs. Therefore, dynamically downscaled regional climate model simulations using boundary conditions from the ERA-Interim global reanalyses (Dee et al., 2011) were used to force the CTMs involved in EDT. Most CTMs used the same meteorological driver, with a couple of exceptions.

One of the meteorological drivers was produced using the Weather Research and Forecast Model (WRF version 3.3.1; Skamarock et al., 2008) at $0.44^{\circ}$ of resolution. In the framework of the EuroCordex climate downscaling programme (Jacob et al., 2013), an evaluation of the regional climate models downscaled with reanalysed boundary conditions (ERA-Interim reanalyses instead of free climate runs) was reported by Kotlarski et al. (2014). One of the WRF realisations in the EuroCordex ensemble was subsequently further optimised as described in Stegehuis et al. (2015), so that we could identify an optimal WRF setup for our purpose (row no. 7 of Table S1 in their Supplement). The model was re-run using grid-nudging towards the ERA-Interim reanalyses (above the planetary boundary layer) in order to improve temporal correlations compared to the regular freerunning Cordex hindcast simulations. This WRF simulation was interpolated on the $25 \mathrm{~km}$ resolution EDT grid and used to drive CHIMERE, EMEP, Polyphemus, and MINNI. In the EMEP model, the interpolation of the meteorological fields from $0.4 \times 0.4^{\circ}$ to EDT grid was performed online. For WRF-Chem, an online model that simulates meteorology and chemistry simultaneously ("online"), the meteorology from the WRF-Eurocordex runs (Stegehuis et al., 2015) was used as initial and lateral boundary conditions and for applying four-dimensional data assimilation (FDDA), with coefficients as described in Mar et al. (2016). The CMAQ model, which runs on a Lambert conformal conic projection, could not use the meteorological data provided on the EuroCordex grid, so that WRF was re-run in a Lambert conformal projection at $25 \mathrm{~km}$ horizontal resolution using identical WRF setup and version (3.3.1).

The CTMs LOTOS-EUROS and MATCH have been meteorologically forced by ERA-Interim series further downscaled with RACMO2 (van Meijgaard, 2012) and HIRLAM (Dahlgren et al., 2016), respectively. RACMO2, used here, was part of the EuroCordex studies documented in Jacob et al. (2013) and Kotlarski et al. (2014) and excludes nudging towards Era-Interim. The HIRLAM EURO4M reanalysis uses data assimilation in three dimensions for upper air and optimal interpolation for surface fields. An initial analysis is conducted every $6 \mathrm{~h}$ with subsequent forecasts saved on 3-hourly temporal resolution. ERA-Interim is forced to the lateral boundaries. The HIRLAM reanalysis was interpolated from the original 0.2 horizontal resolution on a rotated latitude-longitude grid (ca. $22 \mathrm{~km}$ ) to the EDT grid. 


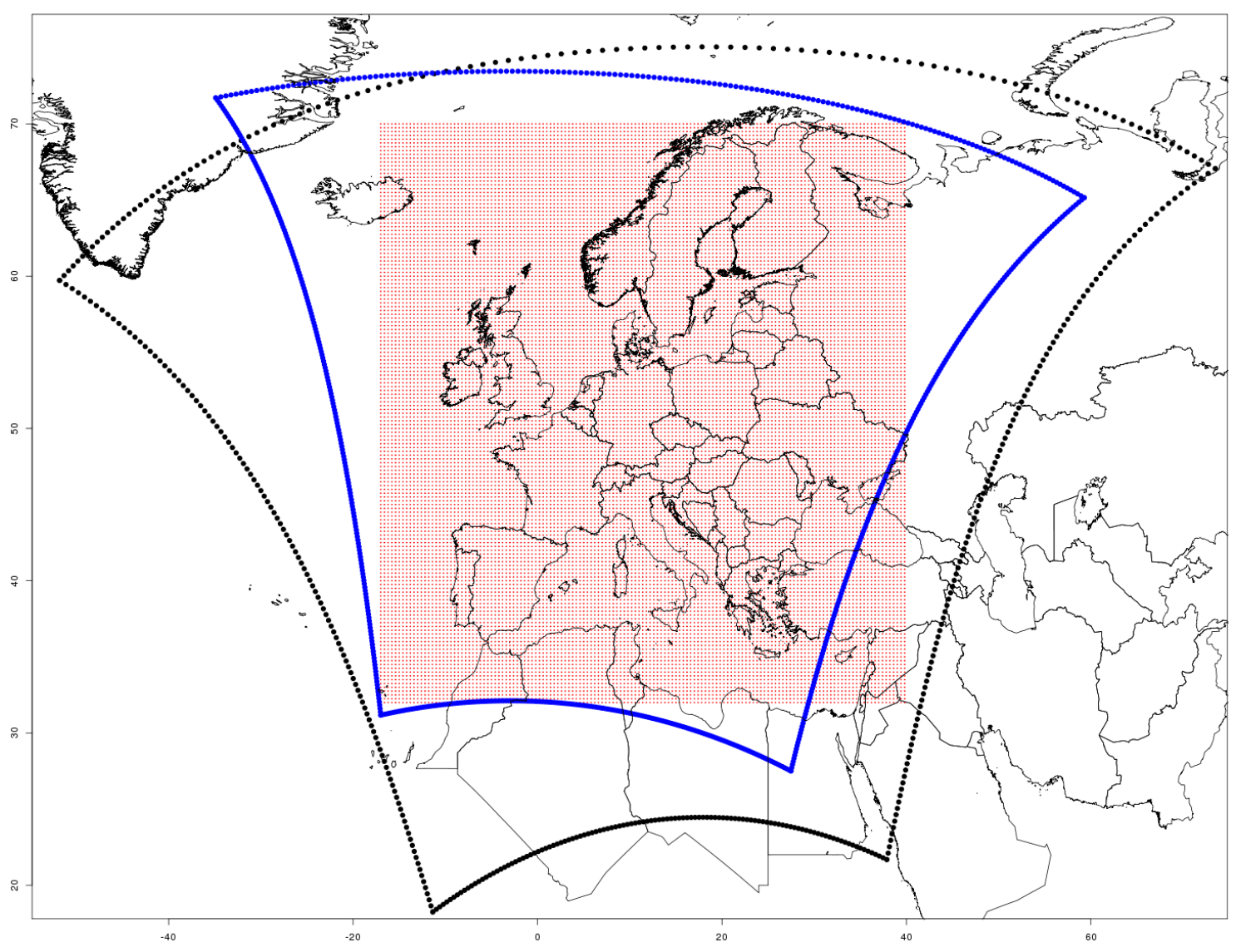

Figure 2. Modelling grid used by all the chemistry transport models involved in EURODELTA-Trends (red dots) with the exception of CMAQB, which could not implement a regular latitude-longitude grid (outer grid cell of the modelling domain displayed with blue dots). The outer grid cells of the meteorological forcing data on the EuroCordex grid are also displayed (black dots).

The main features of the meso-scale meteorological models are synthesised in Table 4.

\section{Emissions}

\subsection{Annual totals of anthropogenic emissions}

National annual emissions, distributed by SNAP (Selected Nomenclature for reporting of Air Pollutants) sectors, were estimated with the GAINS (Greenhouse gases and Air pollution Interactions and Synergies) model (Amann et al., 2011). The calculation was performed for 1990, 1995, 2000, 2005, and 2010 for $\mathrm{SO}_{2}, \mathrm{NO}_{x}$, non-methane volatile organic compounds (NMVOCs), $\mathrm{CO}, \mathrm{NH}_{3}$, and $\mathrm{PM}$ including $\mathrm{PM}_{10}$, $\mathrm{PM}_{2.5}$, black carbon, and organic carbon. To derive emissions for intermediate years, sectorial results for 5-year periods were linearly interpolated.

The key activity data originate from Eurostat ${ }^{1}$ and the International Energy Agency (IEA, 2012) for energy use and from Eurostat, the UN Food and Agriculture Organi-

\footnotetext{
${ }^{1}$ http://ec.europa.eu/eurostat (last access date 14 June 2017)
}

zation $(\mathrm{FAO})^{2}$, and the International Fertilizer Association (IFA) for agriculture. Additionally, for the transport sector, the results of the COPERT model for the EU-28 countries were used (Ntziachristos et al., 2009); these data include detailed transport sources, fuel distribution, mileage, and level of penetration of control measures. The emission calculation considers the impact of existing national and international source-specific emission limits and air quality legislation, e.g. several European Union Directives such as the Large Combustion Plants, Industrial Emissions, and National Emission Ceilings Solvent directives, as well as the UNECE Gothenburg Protocol (UNECE, 1999; Reis et al., 2012). Finally, the results of consultations with national experts, carried out within the work on the review of the National Emission Ceiling Directive (Amann et al., 2012) were considered. This emission dataset was completed in April 2014 and is referred to as ECLIPSE_V5; it is part of a global emission set established during the EU-funded FP7 project ECLIPSE. More detailed description of the data and applied emission calculation methodology is given in Amann et al. (2012) and

\footnotetext{
${ }^{2}$ http://www.fao.org/statistics/en/ (last access date 14 June 2017)
} 
Table 2. Summary of model experiments (including label) with corresponding key scientific questions. The simulations are labelled MyyByyEyy where $\mathrm{M}$ indicates meteorology, B indicates observation-based boundary conditions, C indicates modelling-based boundary condition, E indicates emission, and yy is the 2-digit reference to the corresponding year.

\begin{tabular}{|c|c|c|c|}
\hline Tier & Experiment & Key question (Q)/Action (A) & Label \\
\hline $1 \mathrm{~A}$ & $\begin{array}{l}\text { Meteorology, boundary conditions, and emis- } \\
\text { sions of } 1990,2000 \text { and } 2010 .\end{array}$ & $\begin{array}{l}\text { Q: What is the uncertainty within the seven- } \\
\text { CTM ensemble in } 1990,2000 \text {, and } 2010 \text { ? } \\
\text { A: Comparison } 1 \text { A vs. Observations for } 1990 \text {, } \\
2000 \text { and } 2010\end{array}$ & $\begin{array}{l}\text { M10B10E10 } \\
\text { M00B00E00 } \\
\text { M90B90E90 }\end{array}$ \\
\hline 1B & $\begin{array}{l}\text { Meteorology and boundary conditions of } 2010 . \\
\text { Emissions of } 1990 \text { and } 2000 .\end{array}$ & $\begin{array}{l}\text { Q: What if no emission change occurred in } \mathrm{Eu}- \\
\text { rope? } \\
\text { A: Comparison 1A vs. 1B }\end{array}$ & $\begin{array}{l}\text { M10B10E00 } \\
\text { M10B10E90 }\end{array}$ \\
\hline $2 \mathrm{~A}$ & $\begin{array}{l}\text { Meteorology of } 2010 . \text { Emissions and boundary } \\
\text { conditions of } 1990 \text { and } 2000 .\end{array}$ & $\begin{array}{l}\text { Q: What if no emission changed beyond } \mathrm{Eu}- \\
\text { rope? } \\
\text { A: Comparison 2A vs. 1B }\end{array}$ & $\begin{array}{l}\text { M10B00E00 } \\
\text { M10B90E90 }\end{array}$ \\
\hline 2B & $\begin{array}{l}\text { Meteorology and emissions of } 2010 \text {. } \\
\text { Modelled boundary conditions of } 1990,2000 \text {, } \\
2010\end{array}$ & $\begin{array}{l}\text { Q: What is the uncertainty related to boundary } \\
\text { conditions? } \\
\text { A: Comparison } 2 \text { A vs. } 2 \text { B }\end{array}$ & $\begin{array}{l}\text { M10C10E10 } \\
\text { M00C00E00 } \\
\text { M90C } 90 \mathrm{E} 90\end{array}$ \\
\hline $2 \mathrm{C}$ & $\begin{array}{l}\text { Meteorology of 2000, emissions of } 1990 \text {, and } \\
\text { boundary conditions of } 2000 \text { and } 1990 .\end{array}$ & $\begin{array}{l}\text { Additional simulations for decomposition of } \\
\text { factors in the } 1990 \text { s and } 2000 \text { s }\end{array}$ & $\begin{array}{l}\text { M00B90E90 } \\
\text { M00B00E90 }\end{array}$ \\
\hline $3 \mathrm{~A}$ & 21-year reference trend from 1990 to 2010 & $\begin{array}{l}\text { Q: How do the models capture the trend in ob- } \\
\text { servations? } \\
\text { A: Comparison } 3 \mathrm{~A} \text { vs. observations }\end{array}$ & MyyByyEyy \\
\hline $3 \mathrm{~B}$ & 21-year trend with 2010 emissions & $\begin{array}{l}\text { Q: Does meteorological variability contribute to } \\
\text { the AQ trend over the past } 20 \text { years? } \\
\text { A: Comparison } 3 \mathrm{~A} \text { vs. } 3 \mathrm{~B}\end{array}$ & MyyByyE10 \\
\hline
\end{tabular}

Table 3. Synthesis of models having delivered (D) data to the project database for each of the experiments.

\begin{tabular}{|c|c|c|c|c|c|c|c|c|c|}
\hline Tier & Label & CHIMERE & CMAQB & EMEP & LOTOS-EUROS & MATCH & MINNI & Polyphemus & WRF-Chem \\
\hline \multirow[t]{3}{*}{$1 \mathrm{~A}$} & M10B10E10 & $\mathrm{D}$ & $\mathrm{D}$ & $\mathrm{D}$ & $\mathrm{D}$ & $\mathrm{D}$ & $\mathrm{D}$ & $\mathrm{D}$ & $\mathrm{D}$ \\
\hline & M00B00E00 & $\mathrm{D}$ & $\mathrm{D}$ & $\mathrm{D}$ & $\mathrm{D}$ & $\mathrm{D}$ & $\mathrm{D}$ & $\mathrm{D}$ & $\mathrm{D}$ \\
\hline & M90B90E90 & $\mathrm{D}$ & $\mathrm{D}$ & $\mathrm{D}$ & $\mathrm{D}$ & $\mathrm{D}$ & $\mathrm{D}$ & $\mathrm{D}$ & $\mathrm{D}$ \\
\hline \multirow[t]{2}{*}{ 1B } & M10B10E00 & $\mathrm{D}$ & $\mathrm{D}$ & $\mathrm{D}$ & $\mathrm{D}$ & $\mathrm{D}$ & $\mathrm{D}$ & $\mathrm{D}$ & $\mathrm{D}$ \\
\hline & M10B10E90 & $\mathrm{D}$ & $\mathrm{D}$ & $\mathrm{D}$ & $\mathrm{D}$ & $\mathrm{D}$ & $\mathrm{D}$ & $\mathrm{D}$ & $\mathrm{D}$ \\
\hline \multirow[t]{2}{*}{$2 \mathrm{~A}$} & M10B00E00 & $\mathrm{D}$ & $\mathrm{D}$ & $\mathrm{D}$ & $\mathrm{D}$ & $\mathrm{D}$ & $\mathrm{D}$ & $\mathrm{D}$ & $\mathrm{D}$ \\
\hline & M10B90E90 & $\mathrm{D}$ & $\mathrm{D}$ & $\mathrm{D}$ & $\mathrm{D}$ & $\mathrm{D}$ & $\mathrm{D}$ & $\mathrm{D}$ & $\mathrm{D}$ \\
\hline \multirow[t]{3}{*}{$2 B$} & M10C10E10 & $\mathrm{D}$ & & $\mathrm{D}$ & & & $\mathrm{D}$ & & $\mathrm{D}$ \\
\hline & M00C00E00 & $\mathrm{D}$ & & $\mathrm{D}$ & & & $\mathrm{D}$ & & $\mathrm{D}$ \\
\hline & M90C90E90 & $\mathrm{D}$ & & $\mathrm{D}$ & & & $\mathrm{D}$ & & $\mathrm{D}$ \\
\hline \multirow[t]{2}{*}{$2 \mathrm{C}$} & M00B90E90 & $\mathrm{D}$ & $\mathrm{D}$ & $\mathrm{D}$ & $\mathrm{D}$ & $\mathrm{D}$ & $\mathrm{D}$ & $\mathrm{D}$ & $\mathrm{D}$ \\
\hline & M00B00E90 & $\mathrm{D}$ & $\mathrm{D}$ & $\mathrm{D}$ & $\mathrm{D}$ & $\mathrm{D}$ & $\mathrm{D}$ & $\mathrm{D}$ & $\mathrm{D}$ \\
\hline $3 \mathrm{~A}$ & МyyВууЕуy & $\mathrm{D}$ & & $\mathrm{D}$ & $\mathrm{D}$ & $\mathrm{D}$ & $\mathrm{D}$ & & $\mathrm{D}$ \\
\hline $3 B$ & MyyByyE10 & $\mathrm{D}$ & & $\mathrm{D}$ & $\mathrm{D}$ & $\mathrm{D}$ & $\mathrm{D}$ & & \\
\hline
\end{tabular}


Table 4. Meteorological fields used in the EDT project. WRF-0.44 corresponds an optimised and nudged version of the WRF-IPSL-INERIS Eurocordex member at $0.44^{\circ}$ from the EuroCordex climate downscaling programme (Jacob et al., 2013) used by most CTMs in EDT. WRF-25 corresponds to the WRF run in the same condition as WRF-0.44 in a Lambert conformal conic projection used to drive CMAQB. WRF-Chem indicates the configuration of WRF used within the WRF-Chem online CTM. RACMO2 is the meteorological model used by LOTOS-EUROS.

\begin{tabular}{|c|c|c|c|c|c|}
\hline $\begin{array}{l}\text { Model configu- } \\
\text { ration }\end{array}$ & WRF-0.44 & WRF-25 & WRF-Chem & HIRLAM EURO4M & RACMO2 \\
\hline Model version & WRF v3.3.1 & WRF v3.3.1 & WRF v3.5.1 & $\begin{array}{l}\text { HIRLAM 3DVAR upper air } \\
\text { analysis and OI surface analysis } \\
\text { (for details and evaluation see } \\
\text { Dahlgren et al., 2016) }\end{array}$ & $\begin{array}{l}\text { RACMO2.3 (Meijgaard et al., } \\
\text { 2012) }\end{array}$ \\
\hline $\begin{array}{l}\text { Initial and } \\
\text { boundary } \\
\text { conditions }\end{array}$ & $\begin{array}{l}\text { ERA-Interim } \\
\text { global reanaly- } \\
\text { sis (resolution } \\
\sim 80 \mathrm{~km} \text {; Dee } \\
\text { et al., 2011) }\end{array}$ & $\begin{array}{l}\text { ERA-Interim } \\
\text { global reanaly- } \\
\text { sis (resolution } \\
\sim 80 \mathrm{~km} \text {; Dee } \\
\text { et al., 2011) }\end{array}$ & $\begin{array}{l}\text { WRF- } 0.44 \\
\text { simulation used } \\
\text { by other EDT } \\
\text { models }\end{array}$ & $\begin{array}{l}\text { ERA-Interim global reanalysis } \\
\text { (resolution } \sim 80 \mathrm{~km} \text {; Dee et al., } \\
\text { 2011) }\end{array}$ & $\begin{array}{l}\text { ERA-Interim global reanalysis } \\
\text { (resolution } \sim 80 \mathrm{~km} \text {; Dee et al., } \\
\text { 2011) }\end{array}$ \\
\hline $\begin{array}{l}\text { Coordinate sys- } \\
\text { tem }\end{array}$ & $\begin{array}{l}\text { Rotated latitude } \\
\text { and longitude }\end{array}$ & $\begin{array}{l}\text { Lambert con- } \\
\text { formal }\end{array}$ & $\begin{array}{l}\text { Latitude and } \\
\text { longitude }\end{array}$ & Rotated latitude and longitude & $\begin{array}{l}\text { Rotated latitude and longitude } \\
\text { with a South Pole at } 47^{\circ} \mathrm{S} \text { and } \\
10^{\circ} \mathrm{E} \text {. }\end{array}$ \\
\hline $\begin{array}{l}\text { Horizontal } \\
\text { setting/number } \\
\text { of zonal and } \\
\text { meridional grid } \\
\text { cells }\end{array}$ & $\begin{array}{l}0.44^{\circ} \times 0.44^{\circ} \\
(120-117)\end{array}$ & $\begin{array}{l}25 \mathrm{~km} \times 25 \mathrm{~km} \\
(176-197)\end{array}$ & $\begin{array}{l}\text { Approx. } \\
25 \mathrm{~km} \times 25 \mathrm{~km} \\
(144-154)\end{array}$ & $\begin{array}{l}\text { Approx. } 22 \mathrm{~km} \times 22 \mathrm{~km}(326- \\
341)\end{array}$ & $0.22 \times 0.22(306 \times 220)$ \\
\hline Vertical setting & 31 layers & 31 layers & 34 layers & 60 layers eta coordinates & 40 layers hybrid coordinates \\
\hline Microphysics & 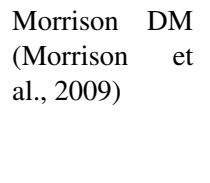 & 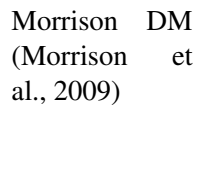 & 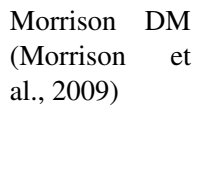 & $\begin{array}{l}\text { Large-scale condensation with } \\
\text { Rasch-Kristjansson scheme } \\
\text { (Rasch and Kristjánsson, 1998) }\end{array}$ & $\begin{array}{l}\text { Prognostic cloud scheme } \\
\text { (Tiedtke, 1993), large-scale } \\
\text { condensation (Tompkins et al., } \\
\text { 2007), boundary layer clouds } \\
\text { (Neggers, 2009) }\end{array}$ \\
\hline $\begin{array}{l}\mathrm{LW}, \mathrm{RW} \\
\text { radiation }\end{array}$ & $\begin{array}{l}\text { RRTMG } \\
\text { (Iacono et al., } \\
2008 \text { ) }\end{array}$ & $\begin{array}{l}\text { RRTMG } \\
\text { (Iacono et al., } \\
2008 \text { ) }\end{array}$ & $\begin{array}{l}\text { RRTMG } \\
\text { (Iacono et al., } \\
2008 \text { ) }\end{array}$ & Savijärvi (1990) & $\begin{array}{l}\text { Shortwave radiation (Clough } \\
\text { et al., 2005; Morcrette et al., } \\
\text { 2008) } \\
\text { Longwave radiation (Mlawer } \\
\text { et al., 1997; Morcrette et al., } \\
\text { 2001) }\end{array}$ \\
\hline $\begin{array}{l}\text { Cumulus } \\
\text { scheme }\end{array}$ & $\begin{array}{l}\text { Tiedtke } \\
\text { (Tiedtke, } \\
\text { 1989; Zhang et } \\
\text { al., 2011) }\end{array}$ & $\begin{array}{l}\text { Tiedtke } \\
\text { (Tiedtke, } \\
\text { 1989; Zhang et } \\
\text { al., 2011) }\end{array}$ & $\begin{array}{l}\text { Grell 3-D } \\
\text { scheme* (Grell } \\
\text { and Dévényi, } \\
\text { 2002) }\end{array}$ & $\begin{array}{l}\text { Convective processes Kain- } \\
\text { Fritsch scheme (Kain, 2004) }\end{array}$ & $\begin{array}{l}\text { Mass flux scheme (Tiedtke, } \\
\text { 1989; Nordeng, 1994; Neggers } \\
\text { et al., 2009; Siebesma et al., } \\
\text { 2007) }\end{array}$ \\
\hline $\begin{array}{l}\text { Boundary \& } \\
\text { Surface layer }\end{array}$ & $\begin{array}{l}\text { MYNN-ETA } \\
\text { (Janjic, 2002; } \\
\text { Nakanishi and } \\
\text { Niino, 2006, } \\
\text { 2009) }\end{array}$ & $\begin{array}{l}\text { MYNN-ETA } \\
\text { (Janjic, 2002; } \\
\text { Nakanishi and } \\
\text { Niino, 2006, } \\
\text { 2009) }\end{array}$ & $\begin{array}{l}\text { MYNN-ETA } \\
\text { (Janjic, 2002; } \\
\text { Nakanishi and } \\
\text { Niino, 2006, } \\
\text { 2009) }\end{array}$ & $\begin{array}{l}\text { Turbulence CBR scheme } \\
\text { (Cuxart et al., 2000); adaptions } \\
\text { for moist CBR (Tijm and } \\
\text { Lenderink, 2003) }\end{array}$ & $\begin{array}{l}\text { Eddy-diffusivity mass flux } \\
\text { scheme with TKE prognostic } \\
\text { variable (Lenderink and Holt- } \\
\text { slag, 2004; Siebesma et al., } \\
\text { 2007) }\end{array}$ \\
\hline Soil & $\begin{array}{l}\text { NOAH (Tewari } \\
\text { et al., 2004) }\end{array}$ & $\begin{array}{l}\text { NOAH (Tewari } \\
\text { et al., 2004) }\end{array}$ & $\begin{array}{l}\text { NOAH (Tewari } \\
\text { et al., 2004) }\end{array}$ & $\begin{array}{l}\text { Further developed ISBA } \\
\text { scheme (Noilhan and Planton, } \\
\text { 1989; Noilhan and Mahfouf, } \\
\text { 1996; Gollvik and Samuelsson, } \\
\text { 2010) }\end{array}$ & $\begin{array}{l}\text { TESSEL (Van den Hurk et al., } \\
\text { 2000), HTESSEL (Balsamo et } \\
\text { al., 2009) }\end{array}$ \\
\hline
\end{tabular}

\footnotetext{
* A different scheme was chosen for compatibility with chemistry, in particular so that there would be sub-grid convective transport of chemical species.
} 
Klimont et al. (2017a, b). The respective scenario is available in the freely accessible online version of the GAINS model ${ }^{3}$ where more detailed outputs and all data inputs can be found.

\subsection{Spatial distribution of anthropogenic emissions}

The emissions were provided by INERIS for the EDT modelling domain using the spatial re-gridding methodology introduced in Terrenoire et al. (2015) and Bessagnet et al. (2016), which consists of the following:

- Europe-wide road and shipping proxies for SNAP sectors 7 and 8 (road transport and other mobile sources and machinery);

- A proxy based on the population density for residential emissions (SNAP 2: non-industrial combustion plants); note that emissions are not linearly proportional to the population density, therefore a fit tested with the bottom-up inventory for France is used;

- For industrial emissions (SNAP 1, 3, and 4: combustion in energy and transformation industries; combustion in manufacturing industry; production processes) we use the flux and location from the EPRTR inventory ${ }^{4}$. When the total emissions exceed the flux reported in EPRTR, we used a default pattern applying the CEIP spatial distribution, available by SNAP sectors ("emissions as used in EMEP models"5). The only exception is for particulate matter emissions for which a spatial distribution was not available for 1990; for that year a combination of officially reported emissions was produced by order of priority: SNAP, NRF01, NFR02, and NFR09 (NFR standing for "Nomenclature for Reporting" following the 2001, 2002, or 2009 guidelines).

- Bottom-up emission inventories for all SNAP inventories for France and the UK (such information was not available elsewhere);

- TNO-MACC inventory for $\mathrm{NH}_{3}$ emissions (largely dominated by SNAP 10: agricultural emissions);

- Default CEIP spatial distribution at a $50 \mathrm{~km}$ resolution for the other sectors (SNAP5, 6, 9: Extraction and distribution of fossil fuels and geothermal energy, Solvents and other product use, Waste treatment and disposal).

In the applied method, only the spatial distribution of industrial emissions is supposed to have changed in time over the past decades. For the residential and road sector, it was considered that the recent techniques involving consistent

\footnotetext{
${ }^{3}$ http://magcat.iiasa.ac.at (last access date 14 June 2017); select "Europe" in order to access respective data and results

${ }^{4} \mathrm{http} / / /$ prtr.ec.europa.eu (last access date 14 June 2017)

${ }^{5}$ http://www.ceip.at/ (last access date 14 June 2017)
}

and high-resolution proxies over Europe provide a more realistic view of emissions than the $50 \mathrm{~km}$ resolution emission data from the 1990s and early 2000s.

\subsection{Biogenic and natural emissions}

There were no specific constraints imposed to biogenic emissions (including soil NO emission) which are represented by most CTMs using an online module. Forest fires were ignored and each modelling team could decide whether they would include lightning as well as natural and dust emissions from road resuspension of dust emissions (see also the synthesis in Table 1).

\section{Chemical boundary conditions}

Two sources of lateral and top chemical boundary conditions are used by the regional CTMs: a climatology of observational data and global model results. Both have pros and cons. Global models carry biases but include a wider array of chemical species. The trend in observations matches in situ data by nature, but only at one point over the domain. For the EDT experiment the consensus in the experiment design was in favour of observation-based boundary conditions for most experiments (tier 1A, 1B, 2A, 2C, 3A, 3B) but also includes a sensitivity study based on modelled boundary conditions (tier 2B).

Note that a possible impact of changing chemistry composition on large-scale circulation was integrated in the forcing meteorological fields through the data assimilation of the ERA-Interim reanalysis. This factor was not considered important to isolate for the 2-decade timescale of the experiment.

Note also that both sources are provided on the basis of monthly averages so that sporadic advection of large intercontinental pollution plumes or dust events will not be captured, although their impact on monthly means is taken into account.

\subsection{Observation-based boundary conditions}

The boundary conditions are a simplified version of those used in the standard EMEP/MSC-W model (Simpson et al., 2012a). The values are based upon climatological data (except from those for natural particles). The most important gaseous boundary condition compounds are $\mathrm{O}_{3}, \mathrm{CO}$, and $\mathrm{CH}_{4}$. For ozone, the three-dimensional climatology based on observational vertical profiles constructed by Logan (1998) are used in conjunction with a temporal (monthly) variation over the past 20 years. These climatological values are modified each month to ensure that their variability matches the observed variability of concentrations in the clean westerly Atlantic air masses as measured at Mace Head on the coast of Ireland. The "Mace Head correction" has been derived for each year from ozone data from Mace Head, sorted using 
sector analysis (based on trajectories obtained from MSC$\left.\mathrm{W}^{6}\right)$. Monthly mean values of the ozone associated with easterly sectors have been calculated for respective years and months, as described in Simpson et al. (2012a).

For methane, uniform boundary conditions around the European domain are set to $1780 \mathrm{ppb}$ in $1990,1820 \mathrm{ppb}$ in 2000 , and $1870 \mathrm{ppb}$ in 2010 according to Mace Head observations. For the intermediary years, an interpolation is applied.

For sulfate $\left(\mathrm{SO}_{4}^{2-}\right)$ and nitrate $\left(\mathrm{NO}_{3}^{-}\right)$aerosols, the trends for 1990-2010 are derived from the trend in EPA emissions for North America of $\mathrm{SO}_{2}$ and $\mathrm{NO}_{x}$ (Hicks et al., $2002 \mathrm{~b})^{7}$. For ammonium $\left(\mathrm{NH}_{4}^{+}\right)$, the trends are derived as $2 / 3 \times \mathrm{SO}_{4}^{2-}+1 / 3 \times \mathrm{NO}_{x}$. The rationale for $\mathrm{SO}_{2}$ lies in the demonstration of the close correspondence between national emissions and the concentration trend in Hicks et al. (2002a).

Monthly (three-dimensional) boundary conditions for sea salt and windblown mineral dust are constructed based on a global run performed with the EMEP/MSC-W model for 2012. The description of EMEP parameterisation for sea spray and windblown dust can be found in Simpson et al. (2012b). The accuracy of the model results for sea salt and mineral dust is regularly evaluated with available observations over Europe and documented in EMEP reports ${ }^{6}$. Model evaluation for mineral dust is limited due to the scarcity of dust in situ measurements, and therefore AOD (aerosol optical depth) and extinction measurements from satellite, AERONET, and EARLINET have also been used recently for model evaluation within AeroCom ${ }^{8}$.

The uncertainty of these observation-based boundary condition trends is important and needs to be addressed in the forthcoming analyses of the experiment results, also including a comparison with the model-based boundary conditions.

\subsection{Global-model-based boundary conditions}

A global model simulation from the Climate-Chemistry Model Initiative (CCMI) is also used in EDT. CCMI undertakes a global atmospheric chemistry reanalysis over the 1960-2010 time period (Eyring, 2014) based on the MACCity emissions (Granier et al., 2011). The CAM4-chem (Tilmes et al., 2016) member of the CCMI ensemble was made available at monthly temporal resolution for use in EDT.

The model uses a full tropospheric and stratospheric chemistry scheme (Lamarque et al., 2012) based on MOZART (Model for Ozone and Related chemical Tracers) version 4 (Emmons et al., 2010). CAM4-chem considers 56 vertical levels from the surface to about $40 \mathrm{~km}$ with $1.9^{\circ} \times 2.5^{\circ}$ horizontal resolution. The simulation used in this analysis was performed in nudging the model to meteorological fields from the MERRA GEOS-5 (Modern Era Retrospective Anal-

\footnotetext{
${ }^{6}$ http://www.emep.int (last access date 14 June 2017)

${ }^{7}$ https://www.epa.gov/air-trends (last access date 14 June 2017)

${ }^{8}$ http://aerocom.met.no (last access date 14 June 2017)
}

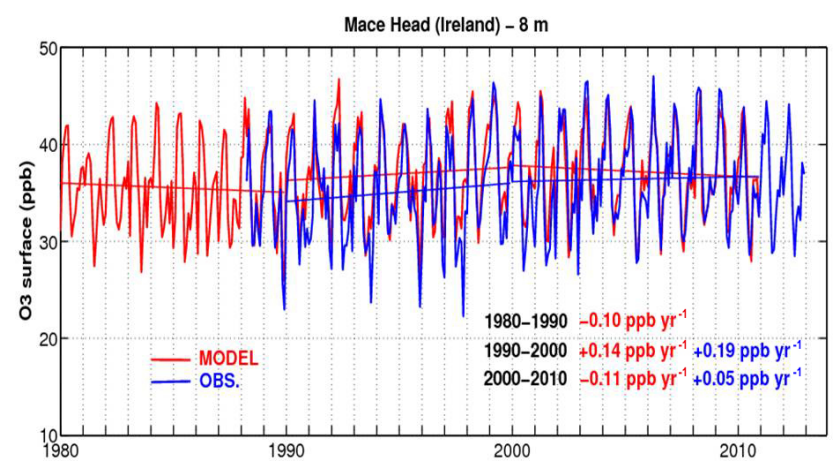

Figure 3. Monthly variation of surface ozone $\left(\right.$ ppb year $\left.^{-1}\right)$ at the Mace Head station observed (blue) and modelled (red) in the CamChem member of the Climate-Chemistry Model Initiative (CCMI).

ysis for Research and Application Goddard Earth Observing System Data Assimilation System Version 5) reanalysis provided by the Global Modelling and Assimilation Office (GMAO).

Evaluation of this global reanalysis is ongoing, but the preliminary results are encouraging, as illustrated in Fig. 3 which shows the modelled and observed ozone trend at the Mace Head station.

\section{Output format and database status}

The model simulations were delivered in a common NetCDF format, so that each of the files contains gridded fields of one pollutant for a whole year. The air pollutant concentrations from only the lowest model level (or corrected to $3 \mathrm{~m}$ height for EMEP, LOTOS-EUROS, and MATCH) are delivered to the project database, but the participants are encouraged to store three-dimensional data if their storage capacities allow such an archiving.

The requested variables are as follows:

- Hourly concentrations of $\mathrm{O}_{3}$ (O3_HL) and $\mathrm{NO}_{2}$ $\left(\mathrm{NO}_{2} \_\mathrm{HL}\right)$;

- Daily concentrations of aerosols (nitrate $\left(\mathrm{NO}_{3}^{-}\right)$, sulfate $\left(\mathrm{SO}_{4}^{2-}\right)$ and ammonia $\left.\left(\mathrm{NH}_{4}^{+}\right)\right)$, sea-salt, dust, total primary $\mathrm{PM}$, anthropogenic and biogenic secondary organic aerosols, and total PM, for both the fraction below $2.5 \mu \mathrm{m}\left(\mathrm{PM}_{2.5}\right)$ and the fraction below $10 \mu \mathrm{m}\left(\mathrm{PM}_{10}\right)$;

- Daily concentrations of reactive gases: $\mathrm{NH}_{3}, \mathrm{SO}_{2}$, an indicator of alpha-pinene that shall depend on the chemical mechanism of each model, isoprene, $\mathrm{HNO}_{3}, \mathrm{H}_{2} \mathrm{O}_{2}$, HCHO, PAN, total VOC, and biogenic VOC;

- Daily emission rate of biogenic species: isoprene and an indicator of alpha-pinene that shall depend on the chemical mechanism of each model; 
(a) $1990 \mathrm{O}_{3} 8 \mathrm{~h} \mathrm{Max} \mathrm{JJA}$

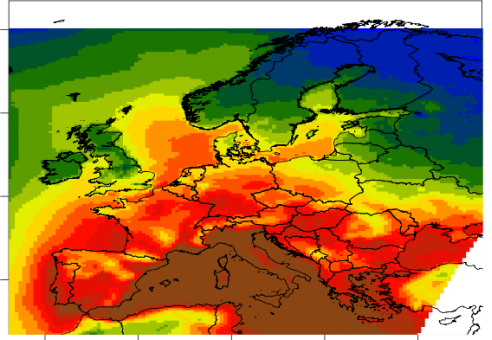

(c) $1990 \mathrm{O}_{3} 8 \mathrm{~h} \mathrm{Max} \mathrm{JJA}$

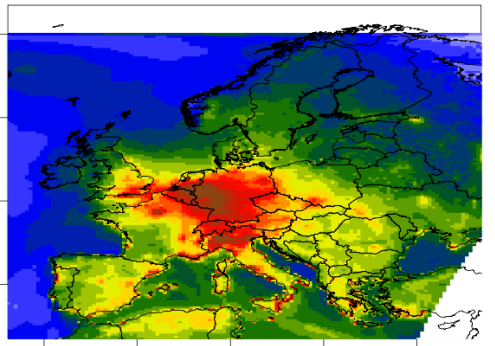

(b) $2010 \mathrm{O}_{3} 8 \mathrm{~h} \mathrm{Max} \mathrm{JJA}$
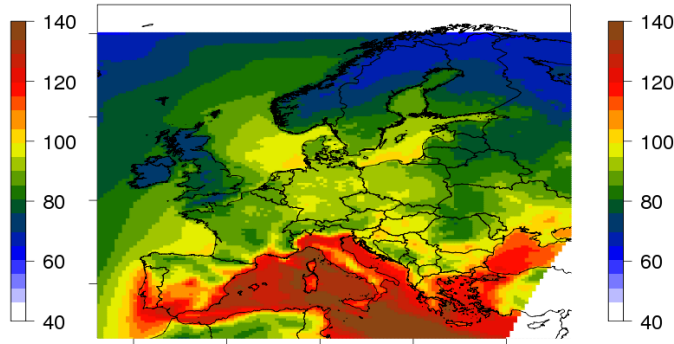

(d) $2010 \mathrm{O}_{3} 8 \mathrm{~h} \mathrm{Max} \mathrm{JJA}$

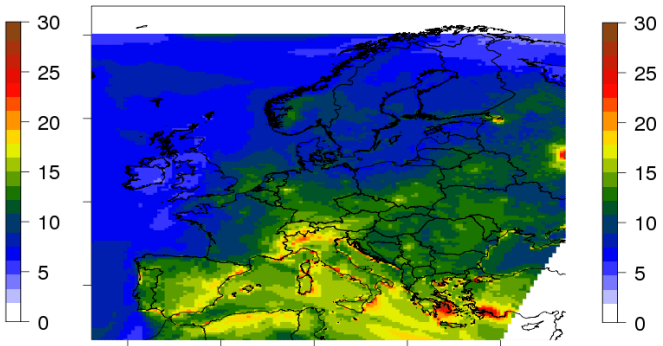

Figure 4. Eight-model ensemble results for 1990 (a, c) and 2010 (b, d) for summertime ozone peaks (June-July-August means of 8 h mean daily maxima, $\left.\mu \mathrm{g} \mathrm{m}^{-3}\right)$. (a, b) Ensemble median, (c, d) ensemble spread (standard deviation).

(a)

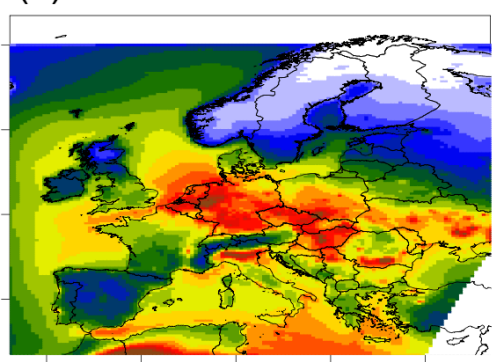

(c)

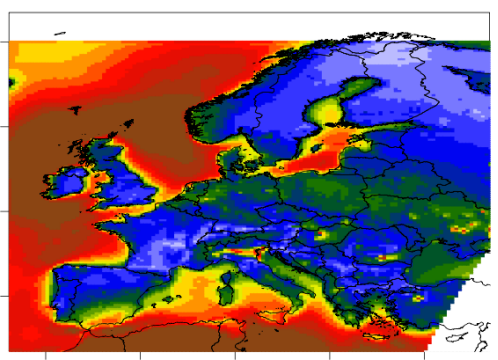

(b)
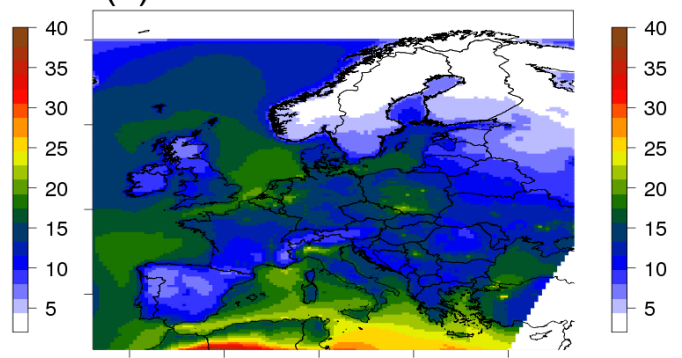

(d)

$2010 \mathrm{PM}_{10}$
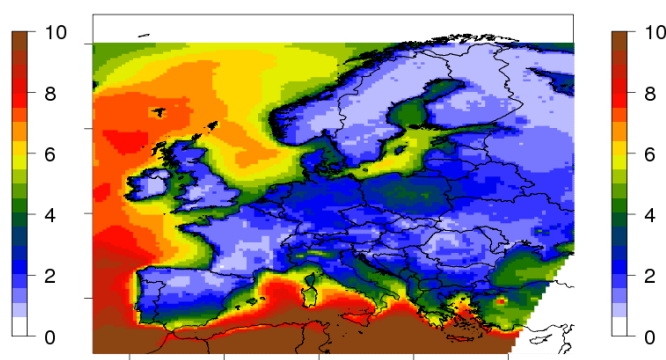

Figure 5. Eight-models ensemble results for 1990 (a, c) and 2010 (b, d) for annual mean $\mathrm{PM}_{10}\left(\mu \mathrm{g} \mathrm{m}{ }^{-3}\right)$. (a, b) Ensemble median, (c, d) ensemble spread (standard deviation).

- Monthly dry and wet deposition of total oxidised sulfur $\left(\mathrm{SO}_{x}\right)$, oxidised nitrogen $\left(\mathrm{NO}_{x}\right)$, and reduced nitrogen $\left(\mathrm{NH}_{x}\right)$

- Hourly meteorological fields: temperature at $2 \mathrm{~m}$, wind speed, PBL, and rain.
Additional diagnostics were subsequently computed and delivered on the common database; the list of indicators and their definitions is available in Table 5 .

The status of models' delivery of results for each of the experiment tiers at the time of submission of the present article is summarised in Table 3 . The access to the database is 
Table 5. List and definition of air pollution indicators derived from the model results and available in the project database.

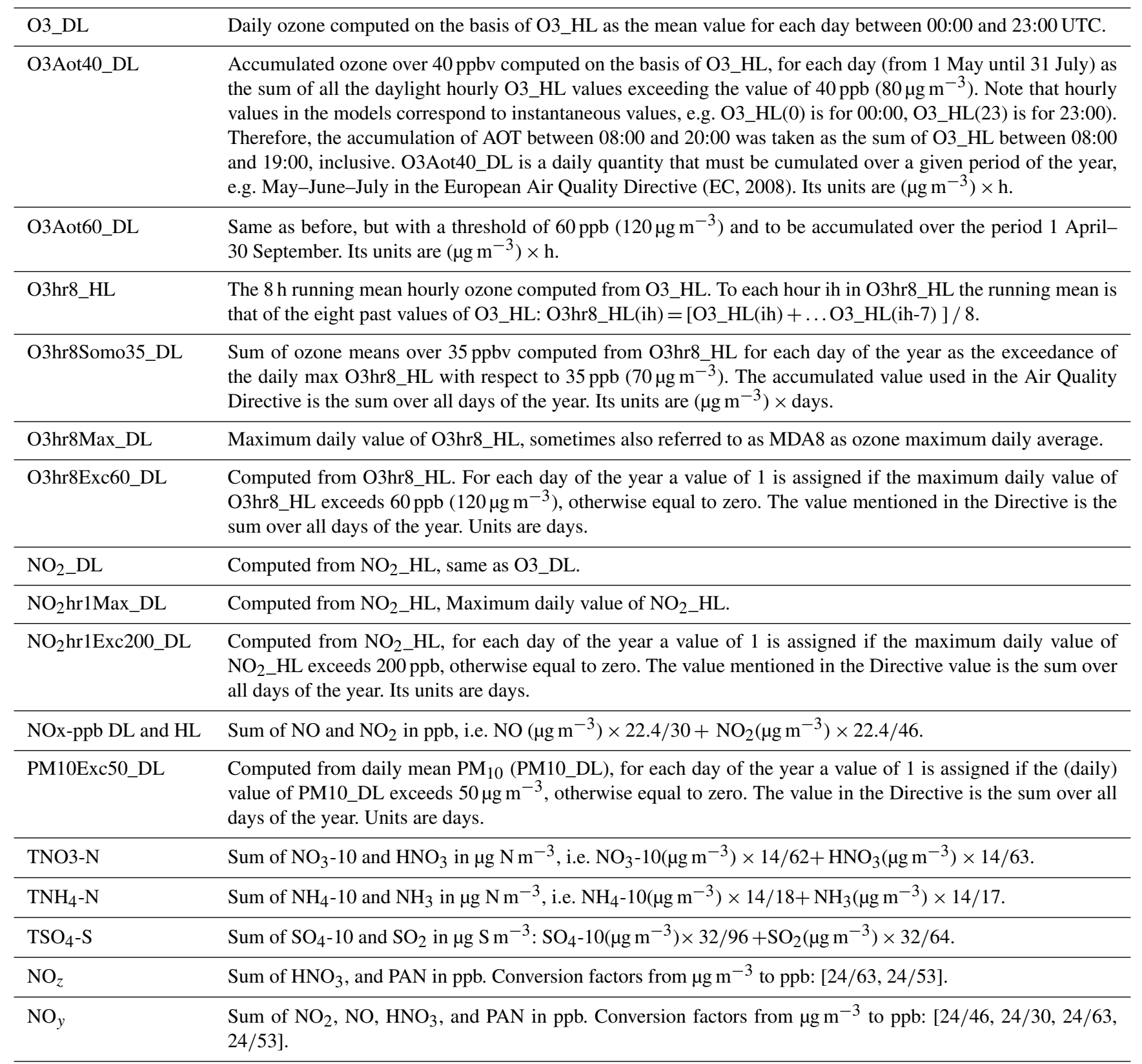

open for research use through the AeroCom server (see also the section on data availability $)^{9}$.

\section{Sample results}

A few illustrations of the results of the Eurodelta-Trend multi-model air quality hindcast are provided in Figs. 4 and 5 with ensemble-median and ensemble-spread concentration maps of ozone and particulate matter in 1990 and 2010,

\footnotetext{
${ }^{9}$ https://wiki.met.no/aerocom/user-server (last access date 14 June 2017)
}

obtained from the eight models which delivered output to tier 1A. For ozone, we show the summertime (June-JulyAugust) average of the daily maxima of $8 \mathrm{~h}$ mean ozone. For particulate matter, the annual mean $\mathrm{PM}_{10}$ is presented.

It is the ambition of the whole Eurodelta-Trend experiment to assess how those maps compare with observations, both in terms of spatial variability and temporal trends, and also to further explain the rationale for the changes observed between 1990 and 2010. However, such analyses require substantial work that is left out of the present article devoted to the presentation of the experiment. 
It is worth highlighting, however, that substantial decreases of both ozone peaks and particulate pollution are modelled in the EURODELTA-Trends ensemble between 1990 and 2010. We present here the decrease on the basis of 1990 and 2010 snapshots for the whole eight-model ensemble that contributed to the experiment. But it would require further documentation in terms of trends by comparison with the subset of five models that produced the full set of 21-year trend simulations in tier $3 \mathrm{~A}$.

For summertime ozone, concentrations exceeding the European target value of $120 \mu \mathrm{g} \mathrm{m}^{-3}$ are only found in the greater Mediterranean region in 2010, whereas in the early 1990s, such concentrations affected much larger areas of continental Europe. The spread (standard deviation) of the models is much larger in 1990 than 2010, especially over the polluted areas of Europe at that time.

Particulate matter concentrations also decreased substantially. The largest spread in the eight-member ensemble is found over sea and desert areas (also because absolute concentrations are high over northern Africa), where the differences between the models changes significantly between 1990 and 2010. This raises important questions regarding the uncertainties of the models for natural sources and the role of inter-annual meteorological variability on aerosol concentrations.

\section{Summary and outlook}

The Eurodelta-Trend modelling experiment will allow a better understanding of the evolution of regional-scale air quality over Europe over the 1990-2010 period. This is facilitated by the thoroughly designed modelling plan. Eight modelling teams have participated in the EDT experiment, though with a variable degree of involvement. The base runs of tier 1A, completed with eight participating models, offer a great opportunity to assess the capability of these state-ofthe-art chemistry-transport models to reproduce the observed changes in the concentrations of the main pollutants, including ozone, particulate matter, and its individual components, as well as in precipitation chemistry. This analysis will then be complemented by an assessment of the capability of reproducing the actual trends over the 21 years in the 19902010 period for the models participating in the more demanding tier $3 \mathrm{~A}$ experiment. If this evaluation phase concludes that the skill of these models in capturing air quality evolution is satisfactory, we would then rely on the results of the trend (or decadal-change) calculations and the sensitivity experiments and recommend that they can be used when addressing science and policy questions underlying the evolution of air quality in Europe over the past couple of decades.

The critical policy question lies in the attribution of air quality trends to emission changes, to influx at the boundaries of the European domain, and to interannual meteorological variability (and natural sources of trace species) and will be addressed in a series of upcoming papers. Furthermore, thanks to the multi-model design of the experiment, other scientific questions with regard to the role of specific chemical and physical processes will be investigated in forthcoming studies based on the EURODELTA-Trends results.

The model results will also be publicly distributed in order to serve for in-depth analyses to scientific communities working on the impacts of air pollution on health, ecosystems, or aerosol radiative forcing.

Data availability. Technical details allowing forthcoming replication of the experiment are available on the wiki of the EMEP Task Force on Measurement and Modelling ${ }^{10}$ and that also provides ESGF links to corresponding input forcing data.

The EURODELTA-Trends model results are made available for public use on the AeroCom server ${ }^{11}$ under the following terms:

- Data provided on this server may be used solely for research and education purposes;

- EURODELTA-Trends partners cannot guarantee that the data are correct in all circumstances. Neither do they accept any liability whatsoever for any error or omission in the data, or for any loss or damage arising from its use;

- Data must not be supplied as a whole or in part to any third party without authorisation;

- Articles, papers, or written scientific works of any form, based in whole or in part on data, images or other products supplied by EURODELTA-Trends will contain an acknowledgment concerning the supplied data reading:

- "Modelling data used in the present analysis were produced in the framework of the EURODELTA-Trends Project initiated by the Task Force on Measurement and Modelling of the Convention on Long Range Transboundary Air Pollution. EURODELTA-Trends is coordinated by INERIS and involves modelling teams of BSC, CEREA, CIEMAT, ENEA, IASS, JRC, MET Norway, TNO, SMHI. The views expressed in this study are those of the authors and do not necessarily represent the views of EURODELTA-Trends modelling teams."

- Users of these data must offer co-authorship to the modelling teams for any study submitted for publication until June 2018. The list of modellers is: CHIMERE (Augustin Colette, Florian Couvidat, Bertrand Bessagnet), CMAQ (Maria-Teresa Pay), EMEP (Svetlana Tsyro, Hilde Fagerli, Peter Wind), ex-JRC (Cornelius Cuvelier), LOTOS-EUROS (Astrid Manders), MATCH (Camilla Andersson, Robert Bergström), MINNI (Mihaela Mircea, Gino Briganti, Andrea Cappelletti, Mario Adani, Massimo D'Isidoro), POLR (Valentin Raffort), WRF-Chem (Kathleen A. Mar, Noelia Otero, Narendra Ojha). After this date, users must inform the EURODELTA-Trends coordinator (augustin.colette@ineris.fr) about the expected use of the data.

\footnotetext{
${ }^{10}$ https://wiki.met.no/emep/emep-experts/tfmmtrendeurodelta (last access date: 14 June 2017)

${ }^{11} \mathrm{https}$ ://wiki.met.no/aerocom/user-server (last access date: 14 June 2017)
} 
The coordinator will, in turn, inform a representative from each modelling team.

Competing interests. The authors declare that they have no conflict of interest.

Acknowledgements. The EMEP MSC-W work has been funded by the EMEP Trust fund and has received support from the Research Council of Norway (Programme for Supercomputing) through CPU time granted at the super computers at NTNU in Trondheim, the University of Troms $\varnothing$, and the University of Bergen. Michael Schultz and Anna Maria Katarina Benedictow are also gratefully acknowledged for hosting of the EURODELTA-Trends database on the AEROCOM server.

The GAINS emission trends were produced as part of the FP7 European Research Project ECLIPSE (Evaluating the Climate and Air Quality Impacts of Short-Lived Pollutants); grant no. 282688.

The CHIMERE simulations where performed were made using the TGCC super computers under the GENCI time allocation gen7485, and also with support from the French Ministry in Charge of Ecology.

CMAQB simulations were performed on the MareNostrum Supercomputer hosted by the Barcelona Supercomputing Center. The work developed Maria-Teresa Pay and its related expenses had been funded by the post-doctoral grant Beatriu de Pinós Program (2011 BP-A2 00015), the CICYT project CGL2013-46736-R, and the Severo Ochoa Program awarded by the Spanish Government (SEV2011-00067).

Peter Simmonds and Gerry Spain are acknowledged for Mace Head $\mathrm{O}_{3}$ data.

The CamChem data were produced as part of the CCMI and PEGASOS projects.

The WRF-Chem simulations have been performed on the supercomputer HYDRA (http://www.rzg.mpg.de/).).

The computing resources and the related technical support used for MINNI simulations have been provided by CRESCO/ENEAGRID High Performance Computing infrastructure and its staff. The infrastructure is funded by ENEA, the Italian National Agency for New Technologies, Energy and Sustainable Economic Development and by Italian and European research programmes (http://www.cresco.enea.it/english).

MINNI participation to this project was supported by the "Cooperation Agreement for support to international Conventions, Protocols and related negotiations on air pollution issues", funded by the Italian Ministry for Environment and Territory and Sea. RACMO2 simulations at KNMI to provide meteorological forcings for LOTOS-EUROS were supported by the Dutch Ministry of Infrastructure and the Environment.

The MATCH participation was partly funded by the Swedish Environmental Protection Agency through the research program Swedish Clean Air and Climate (SCAC) and NordForsk through the research programme Nordic WelfAir (grant no. 75007).

RACMO2 simulations at KNMI to provide meteorological forcings for LOTOS-EUROS were supported by the Dutch Ministry of Infrastructure and the Environment.
Edited by: Astrid Kerkweg

Reviewed by: two anonymous referees

\section{References}

Ackermann, I. J., Hass, H., Memmesheimer, M., Ebel, A., Binkowski, F. S., and Shankar, U.: Modal aerosol dynamics model for Europe: development and first applications, Atmos. Environ., 32, 2981-2999, https://doi.org/10.1016/S13522310(98)00006-5, 1998.

Amann, M., Bertok, I., Borken-Kleefeld, J., Cofala, J., Heyes, C., Höglund-Isaksson, L., Klimont, Z., Nguyen, B., Posch, M., Rafaj, P., Sandler, R., Schöpp, W., Wagner, F., and Winiwarter, W.: Cost-effective control of air quality and greenhouse gases in Europe: Modeling and policy applications, Environ. Model. Softw., 26, 1489-1501, 2011.

Amann, M., Borken-Kleefeld, J., Cofala, J., Heyes, C., Klimont, Z., Rafaj, P., Purohit, P., Schoepp, W., and Winiwarter, W.: Future emissions of air pollutants in Europe - Current legislation baseline and the scope for further reductions, IIASA, Laxenburg, Austria, 2012.

Andersson, C., Langner, J., and Bergstrom, R.: Interannual variation and trends in air pollution over Europe due to climate variability during 1958-2001 simulated with a regional CTM coupled to the ERA-40 reanalysis, Tellus B, 59, 77-98, 2007.

Balsamo, G., Viterbo, P., Beljaars, A., van den Hurk, B. J. J. M., Hirschi, M., Betts, A., and Scipal, K.: A revised hydrology for the ECMWF model: Verification from field site to terrestrial water storage and impact in the Integrated Forecast System, J. Hydrometeor., 10, 623-643, https://doi.org/10.1175/2008JHM1068.1, 2009.

Banzhaf, S., Schaap, M., Kerschbaumer, A., Reimer, E., Stern, R., van der Swaluw, E., and Builtjes, P. J. H.: Implementation and evaluation of $\mathrm{pH}$-dependent cloud chemistry and wet deposition in the chemical transport model REM-Calgrid, Atmos. Environ., 49, 378-390, 2012.

Banzhaf, S., Schaap, M., Kranenburg, R., Manders, A. M. M., Segers, A. J., Visschedijk, A. J. H., Denier van der Gon, H. A. C., Kuenen, J. J. P., van Meijgaard, E., van Ulft, L. H., Cofala, J., and Builtjes, P. J. H.: Dynamic model evaluation for secondary inorganic aerosol and its precursors over Europe between 1990 and 2009, Geosci. Model Dev., 8, 1047-1070, https://doi.org/10.5194/gmd-8-1047-2015, 2015.

Beltman, J. B., Hendriks, C., Tum, M., and Schaap, M.: The impact of large scale biomass production on ozone air pollution in Europe, Atmos. Environ., 71, 352-363, 2013.

Bergström, R., Denier van der Gon, H. A. C., Prévôt, A. S. H., Yttri, K. E., and Simpson, D.: Modelling of organic aerosols over Europe (2002-2007) using a volatility basis set (VBS) framework: application of different assumptions regarding the formation of secondary organic aerosol, Atmos. Chem. Phys., 12, 8499-8527, https://doi.org/10.5194/acp-12-8499-2012, 2012.

Bessagnet, B., Pirovano, G., Mircea, M., Cuvelier, C., Aulinger, A., Calori, G., Ciarelli, G., Manders, A., Stern, R., Tsyro, S., García Vivanco, M., Thunis, P., Pay, M.-T., Colette, A., Couvidat, F., Meleux, F., Rouïl, L., Ung, A., Aksoyoglu, S., Baldasano, J. M., Bieser, J., Briganti, G., Cappelletti, A., D’Isidoro, M., Finardi, S., Kranenburg, R., Silibello, C., Carnevale, C., Aas, W., 
Dupont, J.-C., Fagerli, H., Gonzalez, L., Menut, L., Prévôt, A. S. H., Roberts, P., and White, L.: Presentation of the EURODELTA III intercomparison exercise - evaluation of the chemistry transport models' performance on criteria pollutants and joint analysis with meteorology, Atmos. Chem. Phys., 16, 12667-12701, https://doi.org/10.5194/acp-16-12667-2016, 2016.

Binkowski, F. and Shankar, U.: The Regional Particulate Matter Model, 1. Model description and preliminary results, J. Geophys. Res., 100, 26191-26209, 1995.

Binkowski, F. S.: The aerosol portion of Models-3 CMAQ, in: Science Algorithms of the EPA Models-3 Community Multiscale Air Quality (CMAQ) Modeling System, Part II: Chapters 9-18, National Exposure Research Laboratory, US Environmental Protection Agency, Research Triangle Park, NC, 1999.

Bott, A.: A Positive Definite Advection Scheme Obtained by Nonlinear Renormalization of the Advective Fluxes, Mon. Weather Rev., 117, 1006-1015, 1989.

Byun, D. W. and Schere, K. L.: Review of the governing equations, computational algorithms, and other components of the Models3 Community Multiscale Air Quality (CMAQ) Modeling System, Appl. Mech. Rev., 59, 51-77, 2006.

Carlton, A. G., Bhave, P. V., Napelenok, S. L., Edney, E. O., Sarwar, G., Pinder, R. W., Pouliot, G. A., and Houyoux, M.: Model representation of secondary organic aerosol in CMAQv4.7, Environ. Sci. Technol., 44, 8553-8560, 2010.

Carter, W. P. L.:Implementation of the SAPRC-99 Chemical Mechanism into the Models-3 Framework, available at: http://www. engr.ucr.edu/ carter/pubs/s99mod3.pdf, 2000.

Carter, W. P. L.: Condensed atmospheric photooxidation mechanisms for isoprene, Atmos. Environ., 30, 4275-4290, https://doi.org/10.1016/1352-2310(96)00088-X, 1996.

Carter, W. P. L.: Documentation of the SAPRC-99 Chemical Mechanism for VOC Reactivity Assessment, Final Report to California Air Resources Board Contract No. 92-329, and 95-308, available at: http://www.cert.ucr.edu/ carter/absts.htm\#saprc99, 2000.

Chang, J. S., Brost, R. A., Isaksen, I. S. A., Madronich, S., Middleton, P., Stockwell, W. R., and Walcek, C. J.: A Three-dimensional Eulerian Acid Deposition Model: Physical Concepts and Formulation, J. Geophys. Res., 92, 14681-14700, 1987.

Clough, S. A., Shephard, M. W., Mlawer, E. J., Delamere, J. S., Iacono, M. J., Cady-Pereira, K., Boukabara, S., and Brown, P. D.: Atmospheric radiative transfer modeling: A summary of the AER codes, J. Quant. Spectrosc. Ra., 91, 233-244, 2005.

Colette, A., Granier, C., Hodnebrog, Ø., Jakobs, H., Maurizi, A., Nyiri, A., Bessagnet, B., D’Angiola, A., D’Isidoro, M., Gauss, M., Meleux, F., Memmesheimer, M., Mieville, A., Rouïl, L., Russo, F., Solberg, S., Stordal, F., and Tampieri, F.: Air quality trends in Europe over the past decade: a first multimodel assessment, Atmos. Chem. Phys., 11, 11657-11678, https://doi.org/10.5194/acp-11-11657-2011, 2011.

Colette, A., Aas, W., Banin, L., Braban, C. F., Ferm, M., González Ortiz, A., Ilyin, I., Mar, K., Pandolfi, M., Putaud, J.-P., Shatalov, V., Solberg, S., Spindler, G., Tarasova, O., Vana, M., Adani, M., Almodovar, P., Berton, E., Bessagnet, B., Bohlin-Nizzetto, P., Boruvkova, J., Breivik, K., Briganti, G., Cappelletti, A., Cuvelier, K., Derwent, R., D’Isidoro, M., Fagerli, H., Funk, C., Garcia Vivanco, M., Haeuber, R., Hueglin, C., Jenkins, S., Kerr, J., de Leeuw, F., Lynch, J., Manders, A., Mircea, M., Pay, M. T., Prit- ula, D., Querol, X., Raffort, V., Reiss, I., Roustan, Y., Sauvage, S., Scavo, K., Simpson, D., Smith, R. I., Tang, Y. S., Theobald, M., Tørseth, K., Tsyro, S., van Pul, A., Vidic, S., Wallasch, M., and Wind, P.: Air pollution trends in the EMEP region between 1990 and 2012, NILU, Oslo, 2016.

Couvidat, F., Debry, E., Sartelet, K., and Seigneur, C.: A Hydrophilic/Hydrophobic Organic $\left(\mathrm{H}_{2} \mathrm{O}\right)$ model: Model development, evaluation and sensitivity analysis, J. Geophys. Res., 117, D10304, https://doi.org/10.1029/2011JD017214, 2012.

Couvidat, F. and Sartelet, K.: The Secondary Organic Aerosol Processor (SOAP v1.0) model: a unified model with different ranges of complexity based on the molecular surrogate approach, Geosci. Model Dev., 8, 1111-1138, https://doi.org/10.5194/gmd8-1111-2015, 2015

Cuxart J., Bougeault P., and Redelsperger, J.-L.: A turbulence scheme allowing for mesoscale and large-eddy simulations, Q. J. Roy. Meteorol. Soc., 126, 1-30, https://doi.org/10.1002/qj.49712656202, 2000.

Dahlgren, P., Landelius, T., Kållberg, P., and Gollvik, S.: A high-resolution regional reanalysis for Europe. Part 1: Threedimensional reanalysis with the regional HIgh-Resolution Limited-Area Model (HIRLAM), Q. J. Roy. Meteorol. Soc., 142, 2119-2131, https://doi.org/10.1002/qj.2807, 2016.

Dee, D. P., Uppala, S. M., Simmons, A. J., Berrisford, P., Poli, P., Kobayashi, S., Andrae, U., Balmaseda, M. A., Balsamo, G., Bauer, P., Bechtold, P., Beljaars, A. C. M., van de Berg, L., Bidlot, J., Bormann, N., Delsol, C., Dragani, R., Fuentes, M., Geer, A. J., Haimberger, L., Healy, S. B., Hersbach, H., Hólm, E. V., Isaksen, L., Kållberg, P., Köhler, M., Matricardi, M., McNally, A. P., Monge-Sanz, B. M., Morcrette, J. J., Park, B. K., Peubey, C., de Rosnay, P., Tavolato, C., Thépaut, J. N., and Vitart, F.: The ERA-Interim reanalysis: configuration and performance of the data assimilation system, Q. J. Roy. Meteorol. Soc., 137, 553597, 2011.

Denier van der Gon, H., Jozwicka, M., Hendriks, E., Gondwe, M., and Schaap, M.: Mineral dust as a component of particulate matter, Delft, the Netherlands, 2010.

EC: Directive 2008/50/EC of the European Parliament and of the Council of 21 May 2008 on ambient air quality and cleaner air for Europe, European Commission, Brussels, 2008.

Emberson, L. D., Ashmore, M. R., Simpson, D., Tuovinen, J.-P., and Cambridge, H. M.: Towards a model of ozone deposition and stomatal uptake over Europe, Norwegian Meteorological Institute, Oslo, Norway, 57, 2000a.

Emberson, L. D., Ashmore, M. R., Simpson, D., Tuovinen, J.-P., and Cambridge, H. M.: Modelling stomatal ozone flux across Europe, Water Air Soil Pollut., 109, 403-413, 2000b.

EMEP: Transboundary acidification, eutrophication and ground level ozone in Europe, Part I: Unified EMEP model description, EMEP, Oslo, Norway, 2003.

Emmons, L. K., Walters, S., Hess, P. G., Lamarque, J.-F., Pfister, G. G., Fillmore, D., Granier, C., Guenther, A., Kinnison, D., Laepple, T., Orlando, J., Tie, X., Tyndall, G., Wiedinmyer, C., Baughcum, S. L., and Kloster, S.: Description and evaluation of the Model for Ozone and Related chemical Tracers, version 4 (MOZART-4), Geosci. Model Dev., 3, 43-67, https://doi.org/10.5194/gmd-3-43-2010, 2010.

Erisman, J. W., Van Pul, A., and Wyers, P.: Parametrization of surface resistance for the quantification of atmospheric deposition 
of acidifying pollutants and ozone, Atmospheric Environment, 28, 2595-2607, https://doi.org/10.1016/1352-2310(94)90433-2, 1994.

Eyring, V.: Report on the IGAC/SPARC Chemistry-Climate Model Initiative (CCMI) 2013 Science Workshop, 2014.

Galmarini, S., Rao, S. T., and Steyn, D. G.: Preface, Atmos. Environ., 53, 1-3, 2012.

Galmarini, S., Koffi, B., Solazzo, E., Keating, T., Hogrefe, C., Schulz, M., Benedictow, A., Griesfeller, J. J., JanssensMaenhout, G., Carmichael, G., Fu, J., and Dentener, F.: Technical note: Coordination and harmonization of the multi-scale, multi-model activities HTAP2, AQMEII3, and MICS-Asia3: simulations, emission inventories, boundary conditions, and model output formats, Atmos. Chem. Phys., 17, 1543-1555, https://doi.org/10.5194/acp-17-1543-2017, 2017

Gollvik, S. and Samuelsson, P.: A tiled land-surface scheme for HIRLAM, Swedish Meteorological and Hydrological Institute, Norrköping, Sweden, 2010.

Gong, S., Barrie, L., and Blanchet, J.: Modelling sea-salt aerosols in the atmosphere, 1. Model development, J. Geophys. Res., 102, 3805-3818, https://doi.org/10.1029/96JD02953, 1997.

Granier, C., Bessagnet, B., Bond, T., D’Angiola, A., Denier van der Gon, H., Frost, G., Heil, A., Kaiser, J., Kinne, S., Klimont, Z., Kloster, S., Lamarque, J.-F. O., Liousse, C., Masui, T., Meleux, F., Mieville, A., Ohara, T., Raut, J.-C., Riahi, K., Schultz, M., Smith, S., Thompson, A., van Aardenne, J., van der Werf, G., and van Vuuren, D.: Evolution of anthropogenic and biomass burning emissions of air pollutants at global and regional scales during the 1980-2010 period, Clim. Change, 109, 163-190, 2011.

Grell, G. A. and Dévényi, D.: A generalized approach to parameterizing convection combining ensemble and data assimilation techniques, Geophys. Res. Lett., 29, 1693, https://doi.org/10.1029/2002GL015311, 2002.

Grell, G. A., Peckham, S. E., Schmitz, R., McKeen, S. A., Frost, G., Skamarock, W. C., and Eder, B.: Fully coupled "online" chemistry within the WRF model, Atmos. Environ., 39, 6957-6975, https://doi.org/10.1016/j.atmosenv.2005.04.027, 2005.

Guenther, A., Zimmerman, P., Harley, P., Monson, R., and Fall, R.: Isoprene and monoterpene rate variability: model evaluations and sensitivity analyses, J. Geophys. Res., 98, 12609-12617, 1993.

Guenther, A., Zimmerman, P., and Wildermuth, M.: Natural volatile organic compound emission rate estimates for US woodland landscapes, Atmos. Environ., 28, 1197-1210, 1994.

Guenther, A., Karl, T., Harley, P., Wiedinmyer, C., Palmer, P. I., and Geron, C.: Estimates of global terrestrial isoprene emissions using MEGAN (Model of Emissions of Gases and Aerosols from Nature), Atmos. Chem. Phys., 6, 3181-3210, doi10.5194/acp-63181-2006, 2006.

Hicks, B. B., Artz, R. S., Meyers, T. P., and Hosker, R. P.: Trends in eastern US sulfur air quality from the Atmospheric Integrated Research Monitoring Network, J. Geophys. Res.-Atmos., 107, 4143, https://doi.org/10.1029/2000JD000165, 2002a.

Hicks, B. B., Artz, R. S., Meyers, T. P., and Hosker, R. P.: Trends in eastern US sulfur air quality from the Atmospheric Integrated Research Monitoring Network, J. Geophys. Res.-Atmos., 107, 4143, https://doi.org/10.1029/2000JD000165m 2002b.

Hong, S.-Y., Dudhia, J., and Chen, S.-H.: A revised approach to ice microphysical processes for the bulk parameterization of clouds and precipitation, Mon. Weather Rev., 132, 103-120, 2004.
Iacono, M. J., Delamere, J. S., Mlawer, E. J., Shephard, M. W., Clough, S. A., and Collins, W. D.: Radiative forcing by long-lived greenhouse gases: Calculations with the AER radiative transfer models, J. Geophys. Res., 113, D13103, https://doi.org/10.1029/2008JD009944, 2008.

IEA: Energy Statistics of OECD Countries, International Energy Agency Paris, France, 2012.

Im, U., Bianconi, R., Solazzo, E., Kioutsioukis, I., Badia, A., Balzarini, A., Baró, R., Bellasio, R., Brunner, D., and Chemel, C.: Evaluation of operational on-line-coupled regional air quality models over Europe and North America in the context of AQMEII phase 2, Part I: Ozone, Atmos. Environ., 115, 404-420, 2015.

Jacob, D., Petersen, J., Eggert, B., Alias, A., Christensen, O., Bouwer, L., Braun, A., Colette, A., Déqué, M., Georgievski, G., Georgopoulou, E., Gobiet, A., Menut, L., Nikulin, G., Haensler, A., Hempelmann, N., Jones, C., Keuler, K., Kovats, S., Kraner, N., Kotlarski, S., Kriegsmann, A., Martin, E., Meijgaard, E., Moseley, C., Pfeifer, S., Preuschmann, S., Radermacher, C., Radtke, K., Rechid, D., Rounsevell, M., Samuelsson, P., Somot, S., Soussana, J.-F., Teichmann, C., Valentini, R., Vautard, R., Weber, B., and Yiou, P.: EURO-CORDEX: new high-resolution climate change projections for European impact research, Reg. Environ. Change, 1-16, 2013.

Janjic, Z. I.: Nonsingular implementation of the Mellor-Yamada Level 2.5 Scheme in the NCEP Meso model, National Centers for Environmental Prediction, College Park, MD, 61, 2002.

Jericevic, A., Kraljevic, L., Grisogono, B., Fagerli, H., and Vecenaj, $\check{Z}$.: Parameterization of vertical diffusion and the atmospheric boundary layer height determination in the EMEP model, Atmos. Chem. Phys., 10, 341-364, https://doi.org/10.5194/acp-10341-2010, 2010.

Jonson, J. E., Simpson, D., Fagerli, H., and Solberg, S.: Can we explain the trends in European ozone levels?, Atmos. Chem. Phys., 6, 51-66, https://doi.org/10.5194/acp-6-51-2006, 2006.

Kain, J. S.: The Kain-Fritsch Convective Parameterization: An Update, J. Appl. Meteorol., 43, 170-181, https://doi.org/10.1175/15200450(2004)043<0170:TKCPAU>2.0.CO;2, 2004.

Kelly, J. T., Bhave, P. V., Nolte, C. G., Shankar, U., and Foley, K. M.: Simulating emission and chemical evolution of coarse sea-salt particles in the Community Multiscale Air Quality (CMAQ) model, Geosci. Model Dev., 3, 257-273, https://doi.org/10.5194/gmd-3-257-2010, 2010.

Klimont, Z., Hoeglund-Isaksson, L., Heyes, C., Rafaj, P., Schoepp, W., Cofala, J., Purohit, P., Borken-Kleefeld, J., Kupiainen, K., Kiesewetter, G., Winiwarter, W., Amann, M., Zhao, B., Wang, S., Bertok, I., and Sander, R.: Global scenarios of air pollutants and methane: 1990-2050, in preparation, 2017a.

Klimont, Z., Kupiainen, K., Heyes, C., Purohit, P., Cofala, J., Rafaj, P., Borken-Kleefeld, J., and Schöpp, W.: Global anthropogenic emissions of particulate matter including black carbon, Atmos. Chem. Phys., 17, 8681-8723, https://doi.org/10.5194/acp-178681-2017, 2017b.

Koeble, R. and Seufert, G.: Novel Maps for Forest Tree Species in Europe, A Changing Atmosphere, 8th European Symposium on the Physico-Chemical Behaviour of Atmospheric Pollutants, Torino, Italy, 2001. 
Köhler, I., Sausen, R., and Klenner, G.: $\mathrm{NO}_{x}$ production from lightning, The impact of $\mathrm{NO}_{x}$ emissions from aircraft upon the atmosphere at flight altitudes 8-15 km (AERONOX), Deutsche Luft und Raumfahrt, Oberpfaffenhofen, Germany, 1995.

Kotlarski, S., Keuler, K., Christensen, O. B., Colette, A., Déqué, M., Gobiet, A., Goergen, K., Jacob, D., Lüthi, D., van Meijgaard, E., Nikulin, G., Schär, C., Teichmann, C., Vautard, R., Warrach-Sagi, K., and Wulfmeyer, V.: Regional climate modeling on European scales: a joint standard evaluation of the EUROCORDEX RCM ensemble, Geosci. Model Dev., 7, 1297-1333, https://doi.org/10.5194/gmd-7-1297-2014, 2014.

Lamarque, J.-F., Emmons, L. K., Hess, P. G., Kinnison, D. E., Tilmes, S., Vitt, F., Heald, C. L., Holland, E. A., Lauritzen, P. H., Neu, J., Orlando, J. J., Rasch, P. J., and Tyndall, G. K.: CAM-chem: description and evaluation of interactive atmospheric chemistry in the Community Earth System Model, Geosci. Model Dev., 5, 369-411, https://doi.org/10.5194/gmd-5369-2012, 2012.

Lange, R.: Transferrability of a three-dimensional air quality model between two different sites in complex terrain, J. Appl. Meteorol., 78, 665-679, 1989.

Langner, J., Bergström, R., and Pleijel, K.: European scale modeling of sulphur, oxidized nitrogen and photochemical oxidants, Model development and evaluation for the 1994 growing season, Swedish Meteorological and Hydrological Institute, Norrköping, Sweden, 1998.

Lenderink, G. and Holtslag, A. A. M.: An updated lengthscale formulation for turbulent mixing in clear and cloudy boundary layers, Q. J. Roy. Meteorol. Soc., 130, 3405-3427, https://doi.org/10.1256/qj.03.117, 2004.

Logan, J. A.: An analysis of ozonesonde data for the troposphere: Recommendations for testing 3-D models and development of a gridded climatology for troposheric ozone, J. Geophys. Res., 10, 16115-16149, 1998

Maas, R. and Grennfelt , P.: Towards Cleaner Air - Scientific Assessment Report 2016, EMEP-Steering body and Working Group on Effects - Convention on Long-Range Transboundary Air Pollution 2016.

Mailler, S., Menut, L., Khvorostyanov, D., Valari, M., Couvidat, F., Siour, G., Turquety, S., Briant, R., Tuccella, P., Bessagnet, B., Colette, A., Létinois, L., Markakis, K., and Meleux, F.: CHIMERE-2017: from urban to hemispheric chemistrytransport modeling, Geosci. Model Dev., 10, 2397-2423, https://doi.org/10.5194/gmd-10-2397-2017, 2017.

Mallet, V., Quélo, D., Sportisse, B., Ahmed de Biasi, M., Debry, É., Korsakissok, I., Wu, L., Roustan, Y., Sartelet, K., Tombette, M., and Foudhil, H.: Technical Note: The air quality modeling system Polyphemus, Atmos. Chem. Phys., 7, 5479-5487, https://doi.org/10.5194/acp-7-5479-2007, 2007.

Manders, A. M. M., Builtjes, P. J. H., Curier, L., Denier van der Gon, H. A. C., Hendriks, C., Jonkers, S., Kranenburg, R., Kuenen, J., Segers, A. J., Timmermans, R. M. A., Visschedijk, A., Wichink Kruit, R. J., Van Pul, W. A. J., Sauter, F. J., van der Swaluw, E., Swart, D. P. J., Douros, J., Eskes, H., van Meijgaard, E., van Ulft, B., van Velthoven, P., Banzhaf, S., Mues, A., Stern, R., Fu, G., Lu, S., Heemink, A., van Velzen, N., and Schaap, M.: Curriculum Vitae of the LOTOS-EUROS (v2.0) chemistry transport model, Geosci. Model Dev. Discuss., https://doi.org/10.5194/gmd-2017-88, in review, 2017.
Mar, K. A., Ojha, N., Pozzer, A., and Butler, T. M.: Ozone air quality simulations with WRF-Chem (v3.5.1) over Europe: model evaluation and chemical mechanism comparison, Geosci. Model Dev., 9, 3699-3728, https://doi.org/10.5194/gmd-9-3699-2016, 2016.

Martensson, E., Nilsson, E., de Leeuw, G., Cohen, L., and Hansson, H.-C.: Laboratory simulations and parameterisation of the primary marine aerosol production, J. Geophys. Res., 108, 4297, https://doi.org/10.1029/2002JD002263, 2003.

Meijgaard, E. v., van Ulft, L. H., Lenderink, G., de Roode, S. R., Wipfler, L., Boers, R., and Timmermans, R. M. A.: Refinement and application of a regional atmospheric model for climate scenario calculations of Western Europe, KvR 054/12, 44, 2012.

Menut, L., Bessagnet, B., Khvorostyanov, D., Beekmann, M., Blond, N., Colette, A., Coll, I., Curci, G., Foret, G., Hodzic, A., Mailler, S., Meleux, F., Monge, J.-L., Pison, I., Siour, G., Turquety, S., Valari, M., Vautard, R., and Vivanco, M. G.: CHIMERE 2013: a model for regional atmospheric composition modelling, Geosci. Model Dev., 6, 981-1028, https://doi.org/10.5194/gmd-6-981-2013, 2013.

Mircea, M., Grigoras, G., D’Isidoro, M., Righini, G., Adani, M., Briganti, G., Ciancarella, L., Cappelletti, A., Calori, G., Cionni, I., Cremona, G., Finardi, S., Larsen, B. R., Pace, G., Perrino, C., Piersanti, A., Silibello, C., Vitali, L., and Zanini, G.: Impact of grid resolution on aerosol predictions: a case study over Italy, Aerosol Air Qual. Res., 1253-1267, https://doi.org/10.4209/aaqr.2015.02.0058, 2016.

Mlawer, E. J., Taubman, S. J., Brown, P. D., Iacono, M. J., and Clough, S. A.: Radiative transfer for inhomogeneous atmospheres : RRTM, a validated correlated-k model for the longwave, J. Geophys. Res., 102, 16663-16682, 1997.

Monahan, E. C.: The ocean as a source of atmospheric particles, in: The Role of Air-Sea Exchange in Geochemical Cycling, Kluwer Academic Publishers, Dordrecht, Holland, 129-163, 1986.

Morcrette, J.-J., Mlawer, E. J., Iacono, M. J., and Clough, S. A.: Impact of the radiation transfer scheme RRTM in the ECMWF forecasting system, ECMWF, Reading, UK, 2-9, 2001.

Morcrette, J.-J., Barker, H. W., Cole, J. N. S., Iacono, M. J., and Pincus, R.: Impact of a New Radiation Package, McRad, in the ECMWF Integrated Forecasting System, Mon. Weather Rev., 136, 4773-4798, https://doi.org/10.1175/2008MWR2363.1, 2008.

Morrison, H., Thompson, G., and Tatarskii, V.: Impact of Cloud Microphysics on the Development of Trailing Stratiform Precipitation in a Simulated Squall Line: Comparison of One- and TwoMoment Schemes, Mon. Weather Rev., 137, 991-1007, 2009.

Mozurkewich, M.: The dissociation constant of ammonium nitrate and its dependence on temperature, relative humidity and particle size, Atmos. Environ., 27, 261-270, https://doi.org/10.1016/0960-1686(93)90356-4, 1993.

Nakanishi, M. and Niino, H.: An improved Mellor-Yamada level 3 model: its numerical stability and application to a regional prediction of advecting fog, Bound.-Lay. Meteorol., 119, 397-407, 2006.

Nakanishi, M. and Niino, H.: Development of an improved turbulence closure model for the atmospheric boundary layer, J. Meteor. Soc. Jpn., 87, 895-912, 2009. 
Neggers, R. A. J.: A dual mass flux framework for boundary layer convection, Part II: Clouds., J. Atmos. Sci., 66, 1489-1506, https://doi.org/10.1175/2008JAS2636.1, 2009.

Neggers, R. A. J., Koehler, M., and Beljaars, A. C. M.: A dual mass flux framework for boundary layer convection, Part I: Transport., J. Atmos. Sci., 66, 1465-1487, https://doi.org/10.1175/2008JAS2635.1, 2009.

Nenes, A., Pilinis, C., and Pandis, S. N.: ISORROPIA: a new thermodynamic equilibrium model for multiphase multicomponent marine aerosols, Aquat. Geochem., 4, 123-152, 1998.

Nenes, A., Pilinis, C., and Pandis, S. N.: Continued development and testing of a new thermodynamic aerosol module for urban and regional air quality models, Atmos. Environ., 33, 15531560, 1999.

Noilhan, J. and Planton, S.: A Simple Parameterization of Land Surface Processes for Meteorological Models, Mon. Weather Rev., 117, 536-549, https://doi.org/10.1175/15200493(1989)117<0536:ASPOLS>2.0.CO;2, 1989.

Noilhan J. and J.-F., M.: The ISBA land surface parameterization scheme, Global Planet. Change, 145-159, 1996.

Nordeng, T.-E.: Extended versions of the convection parameterization scheme at ECMWF and their impact upon the mean climate and transient activity of the model in the tropics, ECMWF, 1994.

Ntziachristos, L., Gkatzoflias, D., Kouridis, C., and Samaras, Z.: COPERT: A European Road Transport Emission Inventory Model Information Technologies in Environmental Engineering 4th International ICSC Symposium, Thessaloniki, Greece, 2009, 491-504, 2009.

O'Brien, J. J.: A note on the vertical structure of the eddy exchange coefficient in the planetary boundary layer, J. Atmos. Sci., 27, 1213-1215, 1970.

O'Dowd, C. D., Smith, M. H., Consterdine, I. E., and Lowe, J. A.: Marine aerosol, sea-salt, and the marine sulphur cycle: a short review, Atmos. Environ., 31, 73-80, https://doi.org/10.1016/S1352-2310(96)00106-9, 1997.

OECD: The OECD programme on long range transport of air pollutants. Measurements and findings, Paris, 1977.

Pleim, J.: A combined local and nonlocal closure model for the atmospheric boundary layer, Part I: model description and testing, J. Appl. Meteorol. Climatol., 46, 1383-1395, 2007.

Rao, S. T., Galmarini, S., and Puckett, K.: Air Quality Model Evaluation International Initiative (AQMEII): advancing the state of the science in regional photochemical modeling and its applications, B. Am. Meteorol. Soc., 92, 23-30, 2011.

Rasch, P. J. and Kristjánsson, J. E.: A Comparison of the CCM3 Model Climate Using Diagnosed and Predicted Condensate Parameterizations, J. Climate, 11, 1587-1614, https://doi.org/10.1175/15200442(1998)011<1587:ACOTCM>2.0.CO;2, 1998.

Reis, S., Grennfelt, P., Klimont, Z., Amann, M., ApSimon, H., Hettelingh, J.-P., Holland, M., LeGall, A.-C., Maas, R., Posch, M., Spranger, T., Sutton, M. A., and Williams, M.: From Acid Rain to Climate Change, Science, 338, 1153-1154, 2012.

Robertson, L., Langner, J., and Engardt, M.: An Eulerian LimitedArea Atmospheric Transport Model, J. Appl. Meteorol., 38, 190210, 1999.

Savijärvi, H.: Fast Radiation Parameterization Schemes for Mesoscale and Short-Range Forecast Models, J. Appl.
Meteorol., 29, 437-447, https://doi.org/10.1175/15200450(1990)029<0437:FRPSFM>2.0.CO;2, 1990.

Schaap, M., Timmermans, R. M. A., Roemer, M., Boersen, G. A. C., Builtjes, P., Sauter, F., Velders, G., and Beck, J.: The LOTOSEUROS model: description, validation and latest developments, Int. J. Environ. Pollut., 32, 270-290, 2008.

Schaap, M., Manders, A. M. M., Hendriks, E. C. J., Cnossen, J. M., Segers, A. J. S., Denier van der Gon, H., Jozwicka, M., Sauter, F. J., Velders, G. J. M., Matthijsen, J., and Builtjes, P. J. H.: Regional Modelling of Particulate Matter for the Netherlands, Netherlands Research Program on Particulate Matter, 2009.

Schell, B., Ackermann, I. J., Hass, H., Binkowski, F. S., and Ebel, A.: Modelling the formation of secondary organic within a comprehensive air quality model system, J. Geophys. Res., 106, 28275-28293, 2001.

Seinfeld, J. H. and Pandis, S. N.: Atmospheric Chemistry and Physics, From Air Pollution to Climate Change, John Wiley and Sons, I., New York, USA, 1998.

Siebesma, A. P., Soares, P. M. M., and Teixeira, J.: A Combined Eddy-Diffusivity Mass-Flux Approach for the Convective Boundary Layer, J. Atmos. Sci., 64, 1230-1248, https://doi.org/10.1175/JAS3888.1, 2007.

Simpson, D., Guenther, A., Hewitt, C., and Steinbrecher, R.: Biogenic emissions in Europe 1. Estimates and uncertainties, J. Geophys. Res., 100, 22875-22890, 1995.

Simpson, D., Benedictow, A., Berge, H., Bergström, R., Emberson, L. D., Fagerli, H., Flechard, C. R., Hayman, G. D., Gauss, M., Jonson, J. E., Jenkin, M. E., Nyíri, A., Richter, C., Semeena, V. S., Tsyro, S., Tuovinen, J.-P., Valdebenito, Á., and Wind, P.: The EMEP MSC-W chemical transport model - technical description, Atmos. Chem. Phys., 12, 7825-7865, https://doi.org/10.5194/acp-12-7825-2012, 2012a.

Simpson, D., Benedictow, A., Berge, H., Bergström, R., Emberson, L. D., Fagerli, H., Hayman, G. D., Gauss, M., Jonson, J. E., Jenkin, M. E., Nyri, A., Richter, C., Semeena, V. S., Tsyro, S., Tuovinen, J.-P., Valdebenito, A., and Wind, P.: The EMEP MSC-W chemical transport model - Part 1: Model description, Atmos. Chem. Phys. Discuss., 12, 3781-3874, 2012 b.

Skamarock, W. C., Klemp, J. B., Dudhia, J., Gill, D. O., Barker, D. M., Duda, M. G., Huang, X. Y., Wang, W., and Powers, J. G.: A Description of the Advanced Research WRF Version 3, NCAR, 2008.

Slinn, W. G. N.: Precipitation scavenging, US Department of Energy, Washington, DC, 1983.

Sofiev, M., Soares, J., Prank, M., de Leeuw, G., and Kukkonen, J.: A regional-to-global model of emission and transport of sea salt particles in the atmosphere, J. Geophys. Res., 116, D21302, https://doi.org/10.1029/2010JD014713, 2011.

Spee, E. J.: Numerical methods in global transport-chemistry models, PhD thesis, Amsterdam, 1998.

Sportisse, B. and Dubois, L.: Numerical and theoretical investigation of a simplified model for the parameterization of belowcloud scavenging by falling raindrops, Atmos. Environ., 36, 5719-5727, 2002.

Stegehuis, A. I., Vautard, R., Ciais, P., Teuling, A. J., Miralles, D. G., and Wild, M.: An observation-constrained multi-physics WRF ensemble for simulating European mega heat waves, Geosci. Model Dev., 8, 2285-2298, https://doi.org/10.5194/gmd8-2285-2015, 2015. 
Stein, U. and Alpert, P.: Factor separation in numerical simulations, J. Atmos. Sci., 50, 2107-2115, 1993.

Stockwell, W. R., Middleton, P., Chang, J. S., and Tang, X.: The second generation regional acid deposition model chemical mechanism for regional air quality modeling, J. Geophys. Res.-Atmos., 95, 16343-16367, https://doi.org/10.1029/JD095iD10p16343, 1990.

Strand, A. and Hov, O.: A two-dimensional global study of tropospheric ozone production, J. Geophys. Res., 99, 22877-22895, 1994.

Terrenoire, E., Bessagnet, B., Rouïl, L., Tognet, F., Pirovano, G., Létinois, L., Beauchamp, M., Colette, A., Thunis, P., Amann, M., and Menut, L.: High-resolution air quality simulation over Europe with the chemistry transport model CHIMERE, Geosci. Model Dev., 8, 21-42, https://doi.org/10.5194/gmd-8-21-2015, 2015.

Tewari, M., Chen, F., Wang, W., Dudhia, J., LeMone, M. A., Mitchell, K., Ek, M., Gayno, G., Wegiel, J., and Cuenca, R. H.: Implementation and verification of the unified NOAH land surface model in the WRF model, 20th conference on weather analysis and forecasting/16th conference on numerical weather prediction, Seattle, WA, 2004.

Thunis, P., Cuvelier, C., Roberts, P., White, L., Post, L., Tarrason, L., Tsyro, S., Stern, R., Kerschbaumer, A., Rouil, L., Bessagnet, B., Builtjes, J., Schaap, M., Boersen, G., and Bergstroem, R.: Evaluation of a Sectoral Approach to Integrated Assessment Modelling including the Mediterranean Sea, JRC, Ispra, Italy, 2008

Tiedtke, M.: A comprehensive mass flux scheme for cumulus parameterization in large-scale models, Mon. Weather Rev., 117, 1779-1800, 1989.

Tiedtke, M.: Representation of clouds in large-scale models, Mon. Weather Rev., 121, 3040-3061, 1993.

Tijm, A. and Lenderink, G.: Characteristics of CBR and STRACO versions, HIRLAM Newsletter, No. 43, 115-124, 2003.

Tilmes, S., Lamarque, J.-F., Emmons, L. K., Kinnison, D. E., Marsh, D., Garcia, R. R., Smith, A. K., Neely, R. R., Conley, A., Vitt, F., Val Martin, M., Tanimoto, H., Simpson, I., Blake, D. R., and Blake, N.: Representation of the Community Earth System Model (CESM1) CAM4-chem within the ChemistryClimate Model Initiative (CCMI), Geosci. Model Dev., 9, 18531890, https://doi.org/10.5194/gmd-9-1853-2016, 2016.

Tompkins, A. M., Gierens, K., and Rädel, G.: Ice supersaturation in the ECMWF Integrated Forecast System, Q. J. Roy. Meteorol. Soc., 133, 53-63, 2007.

Troen, I. and Mahrt, L.: A simple model of the atmospheric boundary layer: Sensitivity to surface evaporation, Bound.-Lay. Meteorol., 37, 129-148, 1986.

Tsyro, S., Aas, W., Soares, J., Sofiev, M., Berge, H., and Spindler, G.: Modelling of sea salt concentrations over Europe: key uncertainties and comparison with observations, Atmos. Chem. Phys., 11, 10367-10388, https://doi.org/10.5194/acp-11-103672011, 2011.

Tuovinen, J.-P., Ashmore, M., Emberson, L., and Simpson, D.: Testing and improving the EMEP ozone deposition module, Atmos. Environ., 38, 2373-2385, 2004.

UNECE: Protocol to the 1979 Convention on Long-Range Tansboundary Air Pollution to abate acidification, eutrophication and ground-level ozone, 1999.
Van den Hurk, B. J. J. M., Viterbo, P., Beljaars, A. C. M., and Betts, A. K.: Offline validation of the ERA40 surface scheme, ECMWF, 2000.

van Leer, B.: Multidimensional explicit difference schemes for hyperbolic conservation laws, in: Computing Methods in Applied Sciences and Engineering VI, edited by: Lions, R. G. A. J. L., Elsevier, Amsterdam, 1984.

van Loon, M., Vautard, R., Schaap, M., Bergström, R., Bessagnet, B., Brandt, J., Builtjes, P. J. H., Christensen, J. H., Cuvelier, C., Graff, A., Jonson, J. E., Krol, M., Langner, J., Roberts, P., Rouil, L., Stern, R., Tarrasón, L., Thunis, P., Vignati, E., White, L., and Wind, P.: Evaluation of long-term ozone simulations from seven regional air quality models and their ensemble, Atmos. Environ., 41, 2083-2097, 2007.

Van Zanten, M. C., Sauter, F. J., Wichink Kruit, R. J., Van Jaarsveld, J. A., and Van Pul, W. A. J.: Description of the DEPAC module: Dry deposition modelling with DEPAC_GCN2010, Bilthoven, the Netherlands, 2010.

Vautard, R., Bessagnet, B., Chin, M., and Menut, L.: On the contribution of natural Aeolian sources to particulate matter concentrations in Europe: Testing hypotheses with a modelling approach, Atmos. Environ., 39, 3291-3303, https://doi.org/10.1016/j.atmosenv.2005.01.051, 2005.

Vautard, R., Szopa, S., Beekmann, M., Menut, L., Hauglustaine, D. A., Rouil, L., and Roemer, M.: Are decadal anthropogenic emission reductions in Europe consistent with surface ozone observations?, Geophys. Res. Lett., 33, L13810, https://doi.org/10.1029/2006GL026080, 2006.

Venkatram, A. and Pleim, J.: The electrical analogy does not apply to modelling dry deposition of particles, Atmos. Environ., 33 , 3075-3076, 1999.

Walcek, C. J. and Taylor, G. R.: A theoretical method for computing vertical distribution of acidity and sulphate production within cumulus clouds, J. Atmos. Sci., 43, 339-355, 1986.

Walcek, C. J.: Minor flux adjustment near mixing ratio extremes for simplified yet highly accurate monotonic calculation of tracer advection, J. Geophys. Res., 105, 9335-9348, 2000.

Wesely, M. L.: Parameterization of surface resistances to gaseous dry deposition in regional-scale numerical models, Atmos. Environ., 23, 1293-1304, 1989.

Wichink Kruit, R. J., Schaap, M., Sauter, F. J., van der Swaluw, R., E., and Weijers, R.: Improving the understanding of the secondary inorganic aerosol distribution over the Netherlands, TNO, Utrecht, the Netherlands, 2012.

Wilson, R. C., Fleming, Z. L., Monks, P. S., Clain, G., Henne, S., Konovalov, I. B., Szopa, S., and Menut, L.: Have primary emission reduction measures reduced ozone across Europe? An analysis of European rural background ozone trends 1996-2005, Atmos. Chem. Phys., 12, 437-54, https://doi.org/10.5194/acp-12437-2012, 2012.

Yamartino, R. J.: Nonnegative, conserved scalar transport using grid-cell-centered, spectrally constrained Blackman cubics for applications on a variable-thickness mesh, Mon. Weather Rev., 121, 753-763, 1993.

Yarwood, G., Rao, S., Yocke, M., and Whitten, G. Z.: Updates to the Carbon Bond chemical mechanism: CB05, 2005.

Yuan, H., Dai, Y., Xiao, Z., Ji, D., and Shangguan, W.: Reprocessing the MODIS Leaf Area Index Products for Land Surface and 
Climate Modelling, Remote Sens. Environ., 155, 1171-1187, https://doi.org/10.1016/j.rse.2011.01.001, 2011.

Zhang, C., Wang, Y., and Hamilton, K.: Improved representation of boundary layer clouds over the southeast pacific in ARW-WRF using a modified Tiedtke cumulus parameterization scheme, Mon. Weather Rev., 139, 3489-3513, 2011.

Zhang, K. M., Knipping, E. M., Wexler, A. S., Bhave, P. V., and Tonnesen, G. S.: Size distribution of sea-salt emissions as a function of relative humidity, Atmos. Environ., 39, 3373-3379, 2005.
Zhang, L., Gong, S., Padro, J., and Barrie, L.: A size-segregated particle dry deposition scheme for an atmospheric aerosol module, Atmos. Environ., 35, 549-560, 2001.

Zhang, L., Brook, J. R., and Vet, R.: A revised parameterization for gaseous dry deposition in air-quality models, Atmos. Chem. Phys., 3, 2067-2082, https://doi.org/10.5194/acp-3-2067-2003, 2003. 